\title{
Neuroactive Multifunctional Tacrine Congeners with Cholinesterase, Anti-Amyloid Aggregation and Neuroprotective Properties
}

\section{Maria Kozurkova ${ }^{1, *}$, Slavka Hamulakova ${ }^{2}$, Zuzana Gazova ${ }^{3}$, Helena Paulikova ${ }^{4}$ and Pavol Kristian $^{2}$}

1 Department of Biochemistry, Institute of Chemistry, P. J. Šafárik University, Moyzesova 11, Košice, Slovakia

2 Department of Organic Chemistry, Institute of Chemistry, P. J. Šafárik University, Moyzesova 11, Košice, Slovakia; E-Mails: slavka.hamulakova@upjs.sk (S.H.); pavol.kristian@upjs.sk (P.K.)

3 Department of Biophysics, Institute of Experimental Physics, Slovak Academy of Sciences, Watsonova 47, Košice, Slovakia; E-Mail: gazova@saske.sk (Z.G.)

4 Department of Biochemistry and Microbiology, Faculty of Chemical and Food Technology, Slovak University of Technology, Radlinského 9, Bratislava, Slovakia;

E-Mail: helena.paulikova@stuba.sk (H.P.)

* Author to whom correspondence should be addressed; E-Mail: maria.kozurkova@upjs.sk; Tel.: +421-556-223-582; Fax: +421-556-222-124.

Received: 29 December 2010; in revised form: 3 February 2011 / Accepted: 12 February 2011 / Published: 18 February 2011

\begin{abstract}
The review summarizes research into the highly relevant topics of cholinesterase and amyloid aggregation inhibitors connected to tacrine congeners, both of which are associated with neurogenerative diseases. Various opinions will be discussed regarding the dual binding site inhibitors which are characterized by increased inhibitor potency against acetylcholin/butyrylcholine esterase and amyloid formation. It is suggested that these compounds can both raise levels of acetylcholine by binding to the active site, and also prevent amyloid aggregation. In connection with this problem, the mono/dual binding of the multifunctional derivatives of tacrine, their mode of action and their neuroprotective activities are reported. The influence of low molecular compounds on protein amyloid aggregation, which might be considered as a potential therapeutic strategy in the treatment of Alzheimer's disease is also reported. Finally, attention is paid to some physico-chemical factors, such as desolvation energies describing the transfer of the substrate solvated by
\end{abstract}


water, the metal-chelating properties of biometals reacting with amyloid precursor protein, amyloid beta peptide and tau protein.

Keywords: tacrine; acetylcholinesterase inhibitor; amyloid aggregation; Alzheimer's disease

Abbreviations: AChE — acetylcholinesterase; ACh — acetylcholine; AD—Alzheimer's disease; $\mathrm{A} \beta$ - amyloid beta; ACS - American Chemical Society; $h \mathrm{AChE}$ - human aceylcholinesterase; $n \mathrm{AChR}$ - nicotinic acetylcholine receptor; Apaf-1 - apoptotic protease-activating factor-1; Bcl-2 family proteins - B-cell lymphoma 2 family proteins; BuChE-butyrylcholinesterase; CAS - catalytic anionic subsite; ChEI-cholinesterase inhibitors; CNS - central nervous system; CTP450 - cytochrome P450; CYP2D6-cytochrome P450 2D6; CYP3A4cytochrome P450 3A4; THA - tetrahydroacridine; 5-HT-5-hydroxytryptamine receptors; 7-MEOTA - 9-amino-7-methoxy-1,2,3,4-tetrahydroacridine hydrochloride; nNOS - neuronal nitric oxide synthase; NMDA receptors - $N$-methyl-D-aspartate receptors; PAS - peripheral anionic site; PBT2 - tacrine-8-hydroxyquinoline hybrids

\section{Introduction}

Tacrine was first described pharmacologically by Shaw and Bently in Australia [1] in 1949 as an analeptic capable of causing rapid arousal in morphinized dogs and cats. Early clinical applications of tacrine were in the treatment of anesthetic induced delirium [2] and the potentiation of the muscle relaxing effects of succinylcholine [3].

Heilbronn in 1961 [4] was the first to describe the effect of tacrine upon acetylcholinesterase $(\mathrm{AChE})$ and butyrylcholinesterase $(\mathrm{BuChE})$. She demonstrated that the compounds act as a reversible inhibitor being partly competitive with the substrate acetylcholine (ACh) and a more potent inhibitor of BuChE than of AChE [5].

Other than being an enzyme inhibitor, tacrine was found to have other mechanisms which could explain its cholinergic effect. In electrophysiological studies with neurons of Lymnaea stagnalis, tacrine inhibits the slow outward $\mathrm{K}^{+}$current and consequently increases the duration of the action potentials. Moreover, tacrine inhibits the uptake of noradrenaline, dopamine and serotonine. Such uptake inhibition does not seem to occur at the level of the axonal membrane, but instead at the level of the monoaminergic storage granules [6], and thus tacrine might well have some monoaminergic effect [7]. Tacrine was one of the first ChEI to be tested clinically for the treatment of Alzheimer's disease (AD). Numerous studies [8] had been performed on a small group of patients, with physostigmin alone or in combination with lecithin. The initial report by Summers et al. [9] which suggests that a combined oral treatment of tacrine and lecithin improved the condition of patients with $\mathrm{AD}$ has attracted considerable interest, although later studies have failed to demonstrate such marked improvements. Several reasons have been proposed to explain the negative results of these studies; the small sample size used in the research being among the most significant, and the fact that many of the subjects chosen for the study were already in advanced stages of the disease. Also, multiple transmitter deficits are probably present in AD in addition to a loss of neurons in critical areas of the brain, and 
counteracting the former with tacrine alone does not bring about clinically demonstrable benefits [7]. There is also a high incidence of side effects in the use of tacrine-autonomic symptoms such as gastrointestinal disturbance and hypotension. Additionally, the therapeutic index of tacrine is so small that it is both critical and difficult to find the optimum dose, as individual patients vary greatly in their responsiveness to the treatment [10-12].

In this review, we will summarize the research into the development of tacrine derivatives with cholinesterase and amyloid aggregation inhibiting activity in addition to discussing their neuroprotective properties. Although many reviews have been published on this topic with medicinal or pharmaceutical focuses, we will try to contribute from a different view of point, namely from a bioorganic perspective.

\section{Cholinesterse Inhibitors}

Acetylcholinesterase (AChE, E.C.3.1.1.7) and butyrylcholinesterase (BuChE, E.C.3.1.1.8) are enzymes which constitute the group of the cholinesterases. Acetylcholinesterase hydrolyses acetylcholine (AChE) and is mainly associated with nerves and muscles, being typically found on the synapsies, while butyrylcholinesterase, also known as plasma cholinesterase or pseudocholinesterase, hydrolyses butyrylcholine and is synthesized by the liver, being found in large concentrations in serum [13].

All current kinetic models for AChE propose the existence of at least two substrate-binding sites; the active site, near the bottom of the active-site gorge, and the peripheral anionic site (PAS), near its entrance. Binding the ligands at the PAS affects catalytic activity [14-15]. The active site is composed of two subsites. In the catalytic anionic subsite (CAS), it has been proposed that the choline moiety of AChE is stabilized principally via a cation- $\pi$ interaction with Trp84, and also interacts with Glu199 and Phe330 [16]. A similar cation- $\pi$ interaction occurs in human BuChE, where Trp82 interacts with the product choline and the substrate butyrylthiocholine [17]. The PAS contain three principal amino acids; Trp279, Tyr70 and Asp72. This was established by site-directed mutagenesis and by binding of inhibitors. AChE, one of the most crucial enzymes for nerve response and function, catalyzes the hydrolysis of acylcholinesters with a relative specificity for acetylcholine.

Szegletes et al. [18] demonstrated that the primary physiologic role of the PAS is to accelerate the hydrolysis of acetylcholine at low concentrations of acetylcholine. The gorge of the active site is so deep and broad that it can bind many different substrates and inhibitors. The initial step in the catalytic pathway is substrate binding to the PAS, therefore the designing of new type inhibitors of AChE should be based on the hypothesis of dual binding of AChE inhibitors. The PAS can act as an uncompetitive inhibitor binding site. Strong binding of inhibitors at the peripheral site may hinder the entry of acetylcholine to the enzyme gorge. Such types of inhibitors which are able to bind to PAS can act as a steric blocker.

The hydrolysis reaction proceeds with the nucleophilic attack on the carbonyl carbon, acylating the enzyme and liberating choline. This is followed by a rapid hydrolysis of the acylated enzyme yielding acetic acid, and the restoration of the esteratic site. The pathway is similar to a pipeline, where the substrate goes in one end and the products come out at the other end through conformational changes, along with the effect of hydrophobic and electrostatic forces. In mammals, the alternative splicing of a single gene gives rise to three different variants of $\mathrm{AChE}$ (types $\mathrm{R}, \mathrm{H} / \mathrm{E}$, and $\mathrm{T} / \mathrm{S}$ ), which possess the 
same catalytic activity, but with different tissue specific distributions. AChE is a glycoprotein which is present in cells as either a monomer or an oligomer, depending on the type of cells and on the variant of enzyme, but all of them is membrane-bound.

Recent findings indicate that $\mathrm{AChE}$ is involved not only in the correct functioning of the central and peripheral nervous systems, but that it is a ubiquitous molecule which takes part in the regulation of several other processes such as cell growth, locomotion or apoptosis [19].

While AChE has a well established "classical" esterase activity, the physiologic role of BuChE is still controversial. BuChE is an enzyme which is also involved in cholinergic neurotransmission, and which has received increasing attention in recent years [20].

However, BuChE may have a compensatory role in the hydrolysis of $\mathrm{ACh}$ in brains with degenerative changes. Although BuChE activity is lower than that of $\mathrm{AChE}$ in the normal human brain, $\mathrm{BuChE}$ activity is greatly increased in $\mathrm{AD}$ [21-22]. It is possible that these divergent changes are related to the loss of cholinergic synapses and neurons and the increases in glial cells in the AD brain, which suggests that inhibition of $\mathrm{BuChE}$ (in adition to $\mathrm{AChE}$ ) may become more important as $\mathrm{AD}$ progresses. This has raised the hypothesis that inhibitory action on both enzymes could lead to improved therapeutic benefits [20,23-24].

The current therapeutic options for the treatment of $\mathrm{AD}$ are acetylcholinesterase inhibitors, which increase neurotransmission at cholinergic synapses in the brain and reduce temporarily the cognitive deficit [25].

Cholinergic dysfunction can be associated with a decrease in the production of the neurotransmitter acetylcholine. Many approaches leading to enhancing concentration of acetylcholine at the synaptic cleft have been suggested. An understanding of the protein structure and mechanism of catalytic action of AChE is important for the design of a new potent inhibitor of AChE.

\subsection{Tacrine}

Tacrine, 9-amino-1,2,3,4-tetrahydroacridine (Cognex, THA, 1, Figure 1) is a nonclassical acetylcholine inhibitor (AChEI), drug, that binds to both $\mathrm{AChE}$ and $\mathrm{BuChE} \mathrm{[5].}$

Figure 1. Tacrine 1.

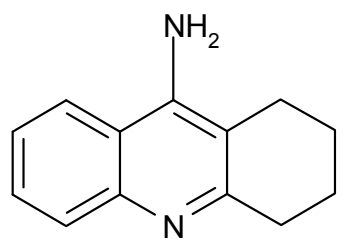

1

In 1993 tacrine was licensed in the US, Canada and parts of Europe as the first agent specifically approved for the treatment of cognitive symptoms of AD (Pfizer and Warner-Lambert, New York, NY). Tacrine is extensively metabolized by cytochrome P450 (CTP450) to at least three metabolites. The major metabolite, 1-hydroxytacrine is active [26]. Approximately $20 \%$ of tacrine-treated patients may show improvement, but its use has been limited due to the severe side effects which have been reported, e.g., hepatotoxicity and gastrointestinal antagonism, which represent important disadvantages [27,28]. It 
is necessary to point out that all inhibitors of $\mathrm{AChE}$ show gastrointestinal side effects to some degree (a consequence of their peripheral cholinergic effects). In general, AChE inhibitors can improve cholinergic transmission but cannot stop the process of neurodegeneration, however some of them are able to inhibit the apoptotic process and these AChE inhibitors possess neuroprotective effects. Use of tacrine has greatly decreased following the recent development of safer AChEIs (galantamine, donepezil, rivastigmine, and Huperzine).

Since tacrine was synthesized in 1945 [29], many analogues have been made and tested for a variety pharmacological effects. Tacrine itself was produced during an investigation into the antibacterial properties of acridine derivatives, and, although it lacks antibacterial effects, it has several other actions. Tacrine was found to antagonize the respiratory depression caused by morphine [2] before it was known to inhibit both acetyl- and butyrylcholineesterase [5] enzymes. Additional effects of tacrine were discovered later: blocking of monoamine oxidase activity [30], inhibition of neuronal uptake of 5-hydroxytryptamine receptors (5-HT), and dopamine [31], blockade of certain potassium ion channels [32], interaction with muscarinic acetylcholine receptors [33]. Various tacrine derivatives such as hydroxyl- [34] and halogenated [35] derivatives, bis-[36] and hetero/homodimers [37], tetracyclic tacrines [38], peptidic-tethered [39] and dihydropyridine derivatives [40] amongst other have been synthesized in an effort to mitigate the side effects concomitant with increasing efficiency. Research was focused on compounds which would simultaneously bind to active and peripheral binding sites. It was suggested that these compounds could raise levels of acetylcholine by binding to the active site, and prevent $A \beta$ aggregation.

\subsection{Non-Tacrine Inhibitors}

Donepezil (Aricept) is another nonclassic, centrally acting, reversible, noncompetitive AChEI that was approved in 1997 for the treatment of mild-to-moderate $\mathrm{AD}$ and dementia (Figure 2). Its selectivity for $\mathrm{AChE}$ is in the periphery. When compared to tacrine, donepezil exhibits greater central nervous system (CNS) AChE selectivity, longer elimination half-life and little or no potential for hepatotoxicity. Donepezil is metabolized by cytochrome P450 2D6 (CYP2D6) and cytochrome P450 3A4 (CYP3A4) via demethylation, debenzylation, hydroxylation, oxidation to the $c i s-N$-oxide and glucuronidation. The 6-O-desmethyl metabolite accounts for $11 \%$ of the dose, and exhibits AChE inhibitory activity comparable to that of the parent compounds [26,41].

Rivastigmin (Exelon) is a centrally selective, arylcarbamate AChEI that was approved in 2000 for oral administration (Figure 2). Because of the slow dissociation of the carbamylated enzyme, it has been referred to as a pseudo-irreversible AChEI. Like donepezil, rivastigmine exhibits a low level of hepatotoxicity. It is rapidly and extensively hydrolyzed in the CNS by cholinesterase with a minimal involvement of CYP450. The phenolic metabolite is excreted primarily via the kidneys [26,41].

Galantamine (Razadyne, Figure 2), which was introduced in 2001, is an alkaloid found in plants of the family Amaryllidaceae, which includes the daffodil (Narcissus pseudonarcissus) and snowflake (Leucojum aestivum). It is a reversible inhibitor of AChE, but it does not appear to inhibit butyrylcholinesterase. In view of the fact that it is a tertiary amine and can cross the blood-brain barrier, it is indicated for the treatment of mild-to-moderate $\mathrm{AD}$ and dementia. It has also been used as an anticutate agent in anesthesia. Galantamine differs from other cholinesterase inhibitors, because it 
allosterically binds to nicotinic receptors, giving it a dual cholinergic action. It is metabolized (75\%) by CYP2D6 and CYP3A4 to create the normethyl, $O$-desmethyl and $O$-desmethylnormethyl metabolites, along with some other minor metabolites. Unlike tacrine, galantamine is not associated with hepatotoxicity $[26,41]$.

Figure 2. Selected AChE inhibitors-donepezil (2); rivastigmin (3); galantamine (4); Huperzine A (5); and flavonoid derivative (6).
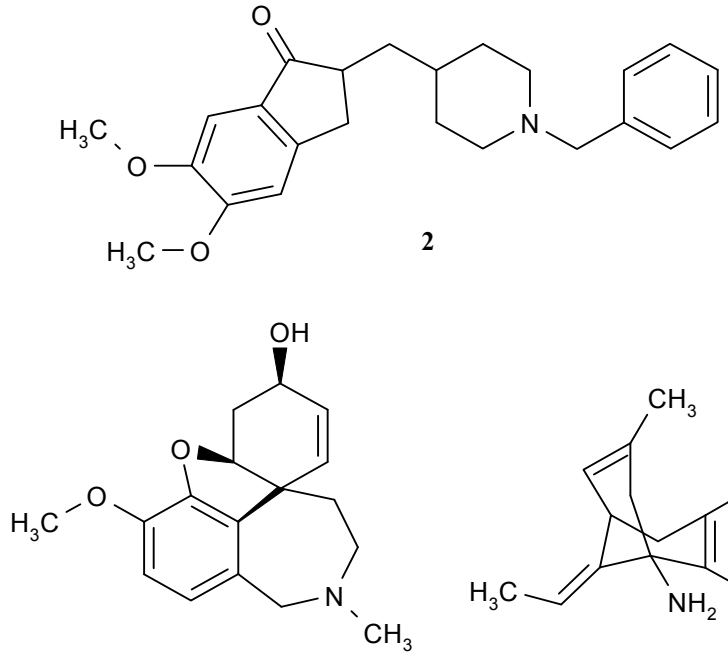

4

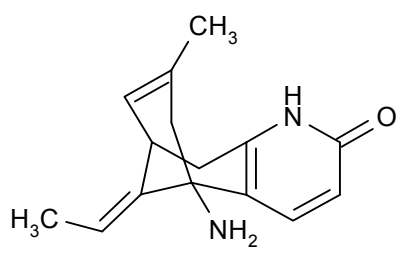

5

Huperzine A, a novel alkaloid isolated from the Chinese club moss plant Huperzia serrata, a member of the Lycopodium species, is a potent, highly specific and reversible inhibitor of AChE (Figure 2). The potency and relative safety of Huperzine A rendered it a promising drug for the ameliorative treatment of AD [42]. Huperzine A temporarily blocks acetylcholinesterase, which is concentrated in the brain, spinal cord, and red blood cells. By reducing the activity of acetylcholinesterase, Huperzine A may help to reduce the breakdown of acetylcholine, thereby keeping more of it in the blood. Several studies of memory-impaired animals and humans have shown that taking Huperzine A may help to relieve dementia. This compound has already been approved in China for the treatment of $\mathrm{AD}$ [43-44].

Compared with tacrine, donepezil, and rivastigmin, Huperzine A has better penetration through the blood-brain barrier, higher oral bioavailability, and longer duration of AChE inhibitory action and fewer peripheral cholinergic side effects [45]. Huperzine A possesses the ability to protect cells against hydrogen peroxide, amyloid beta $(\mathrm{A} \beta)$ peptide, glutamate, ischemia, staurosporine-induced cytotoxicity and apoptosis.

Furthermore, there are a number of interesting compounds which belong to different groups and which also have natural origins - flavonoids. Shen et al. [46] synthesized, designed and evaluated a series of flavonoid derivatives as acetylcholinesterase inhibitors that could bind simultaneously to the peripheral and catalytic sites of the enzyme. Among them, some derivatives were found to inhibit the enzyme in micromolar range and isoflavone derivatives possessed more potent inhibitory activity than other flavonoid derivatives. The best compound (compound 6, Figure 2) had its inhibitory activity in the same range as the reference donepezil. Preliminary structure-activity relationships and a molecular 
modeling study for this compound have revealed that the isoflavone moiety plays a key role in the interaction of this series of derivatives with $\mathrm{AChE}$ by acting as an anchor in its peripheral anionic site.

\subsection{Hybrid Molecules of Tacrine-Improvement of Cholinergic Neurotransmission}

Four inhibitors of AChE are known to have a positive effect on the treatment of AD symptomsdonepezil, rivastigmine, galantamine, and tacrine. These compounds were approved by the U.S. Food and Drug Administration for the treatment of AD. It has been proposed that the PAS of AChE could be somehow related to the aggregation and deposition of $\mathrm{A} \beta$ peptide, which is an early event in the neurodegenerative cascade of AD. These findings have led to an interest in a bi- and multifunctional drugs strategy to simultaneously inhibit ACh hydrolysis and AChE-induced A $\beta$ aggregation. The aim of molecular designers is to develop more effective inhibitors of $\mathrm{AChE}$ than the current inhibitors with neuroprotective effects and with marginal side effects.

New types of inhibitors such as tacrine-based substances with dual binding site PAS and CAS have been prepared and a number of hybrid molecules of tacrine with different bioactive molecules have been designed [37,47-49]. Substances with an ability to modify activity AChE or the other proteins important for preservation of cell viability, e.g., substances with antioxidant capability or ligands of acetylcholine receptors, calcium channels, NMDA and others, have been used as bioactive molecules.

\subsubsection{Monotacrine inhibitors}

Recanatini et al. [50] compared the inhibitory potency of a large series of 9-aminotetrahydroacridine derivatives 7, 8, 9, (Figure 3) to that of $h \mathrm{AChE}$ according to various substituents, R1, R2.

Figure 3. 9-Amino-1,2,3,4-tetrahydroacridine derivatives 7, 8, 9.<smiles>[R2]c1cc2nc3c(c(N)c2cc1[R2])CCCC3</smiles>

7

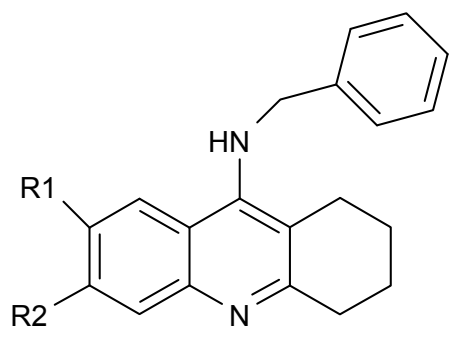

8<smiles>[R2]c1cc2nc3c(c(NCC)c2cc1[R2])CCCC3</smiles>

9

7: $\mathbf{a}, \mathrm{R} 1=\mathrm{CH}_{3}, \mathrm{R} 2=\mathrm{H} ; \mathbf{b}, \mathrm{R} 1=\mathrm{H}, \mathrm{R} 2=\mathrm{CH}_{3} ; \mathbf{c}, \mathrm{R} 1=\mathrm{Cl}, \mathrm{R} 2=\mathrm{H} ; \mathbf{d}, \mathrm{R} 1=\mathrm{H}, \mathrm{R} 2=\mathrm{Cl} ; \mathbf{e}, \mathrm{R} 1=\mathrm{NO}_{2}$, $\mathrm{R} 2=\mathrm{H} ; \mathbf{f}, \mathrm{R} 1=\mathrm{H}, \mathrm{R} 2=\mathrm{NO}_{2}$.

It was found that the chlorine atom, and the $\mathrm{CH}_{3}$ and $\mathrm{NO}_{2}$ groups in the 6-position (compounds $\mathbf{7 b}, \mathbf{d}, \mathbf{f}$ ) were more active AChEIs than the substituents in position 7 (compounds $7 \mathbf{a}, \mathbf{c}, \mathbf{e}$ ). The double substitution of chlorine atoms in 6- and 7- position cancels the effectivity of tacrine derivative. The results show that the biological activity of ligands depends on the electron character of the substituent (electronaceptor substituents increase and electrondonating substituents decrease inhibitory potency). The inhibitory activity of the synthesized compounds are in the range of $\mathrm{IC}_{50}=0.0099 \pm 0.0003 \mu \mathrm{M}$ for compounds $\mathbf{7 d}, \mathrm{IC}_{50}=0.028 \pm 0.001$ for compounds $\mathbf{7 f}$, and $\mathrm{IC}_{50}=5.2 \pm 0.1 \mu \mathrm{M}$. While the benzyl 
group decreases the AChE inhibitory potency for the 6-substituted tacrine analogues (compounds 8) and the $n$-heptyl group, it strongly increases the activity of the 7-methyl analogue (compound 9).

Pisoni and his colleagues [51] focused their attention on a new series of the chiral terpenic tacrine analogues (Figure 4).

Figure 4. Terpenic chiral 9-aminotetrahydroacridine analogues 10a-i.

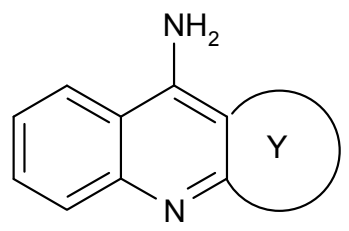

$10 a-\mathbf{i}$

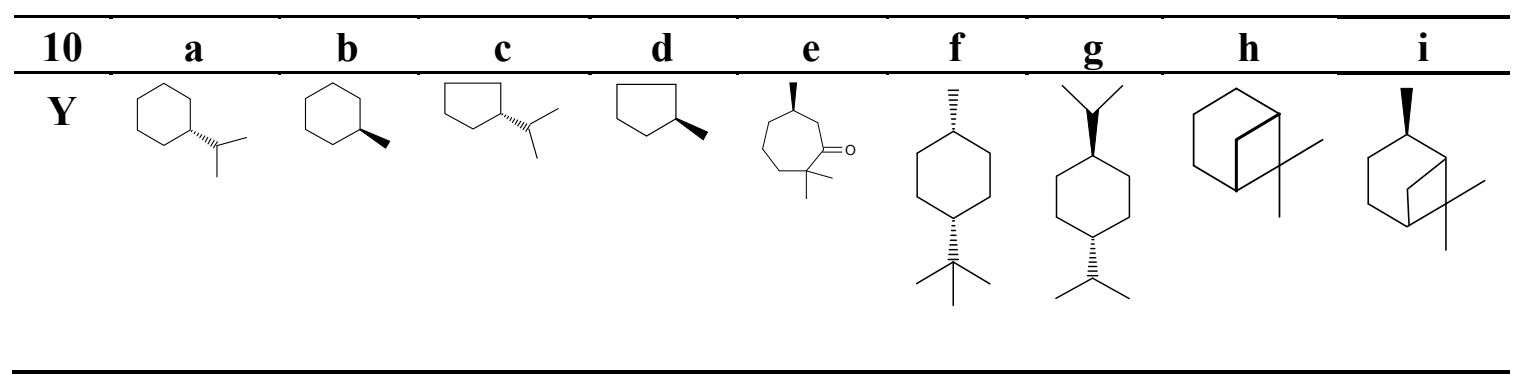

The authors discussed the configuration, the size of the ring and the bulk of substituent, and the increase and decrease of inhibiting potency in comparison with tacrine. The seven-membered analogues 10e were found to be a significantly more potent inhibitor when compared with other compounds $\left(\mathrm{IC}_{50}=0.288 \mu \mathrm{M}\right)$.

Novel tacrine congeners (Figure 5) with side ligands suitable for optimal interaction with the peripheral and catalytic sites of acetyl- and butyrylcholinesterase have been synthesized [52] using either 9-isothiocyanato-1,2,3,4-tetrahydroacridine or 9-chloro-1,2,3,4-tetrahydroacridine.

The synthesized compounds were all tested for their ability to inhibit the activity of both AChE and BuChE. For comparison, tacrine and 9-amino-7-methoxy-1,2,3,4-tetrahydroacridine hydrochloride (7-MEOTA) [52] were used as standards. The most promising inhibition, i.e., the lowest $\mathrm{IC}_{50}$ value, of $\mathrm{AChE}$ by the compounds synthesized in this work was exhibited by $\mathbf{1 4 c}\left(\mathrm{IC}_{50}=0.972 \mu \mathrm{M}\right)$, closely followed by $\mathbf{1 4 b}$ and $\mathbf{1 5 b}\left(\mathbf{1 4 b}: \mathrm{IC}_{50}=1.21 \mu \mathrm{M}\right.$; 15b: $\left.\mathrm{IC}_{50}=1.26 \mu \mathrm{M}\right)$. Although compounds $\mathbf{1 4 b}, \mathbf{c}$ and $\mathbf{1 5 b}$ failed to match the inhibition displayed by tacrine, which was cca an order of magnitude more effective, they were, in fact, more effective in inhibiting AChE than 7-MEOTA. For the inhibition of BuChE, several compounds were comparable to tacrine, 12c: $\mathrm{IC}_{50}=0.503 \mu \mathrm{M}$; 13b: $\mathrm{IC}_{50}=0.812 \mu \mathrm{M}$; 14b: $\mathrm{IC}_{50}=0.0204 \mu \mathrm{M}$; 14c: $\mathrm{IC}_{50}=0.164 \mu \mathrm{M}$ and 15b: $\mathrm{IC}_{50}=0.0823 \mu \mathrm{M}$. Notably, all of the tested compounds exhibited much higher inhibitory activity towards $\mathrm{BuChE}$, the only exception being 7-MEOTA. Indeed, all compounds were more effective inhibitors of $\mathrm{BChE}$ in comparison to 7-MEOTA. The most potent inhibitor of AChE was the morpholine aminoderivative 14c, but, in contrast, the morpholine thiourea 12b was the least active inhibitor. Moreover, the thiourea derivatives studied here were significantly less active. For example, the replacement of sulphur by oxygen $(\mathbf{1 2 b}, \mathbf{1 3 b})$ produced a compound with a three-fold increase in AChE activity and a magnitude increase in BChE activity by nearly two orders. 
Figure 5. 7-MEOTA 11 and novel 9-substituted tacrine congeners 12-15.<smiles></smiles><smiles>[R]NC(=S)Nc1c2c(nc3ccccc13)CCCC2</smiles>

12a-d

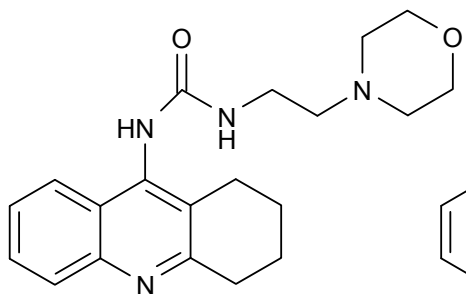

$13 b$<smiles>[R]Nc1c2c(nc3ccccc13)CCCC2</smiles>

R: 12c

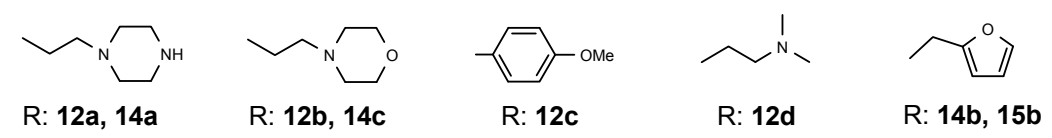<smiles>[R]Nc1c2c(nc3ccccc13)CCCC2</smiles>

$15 b$

A number of papers concerning 7-MEOTA 11 as a new Czech cholinergic drug first synthesized by Patocka et al. [53] have also been published. In connection with the previous obtained results [54-55], fourteen new $\mathrm{N}$-alkyl 7-MEOTA analogs hydrochlorides 16a-n which were found to be less toxic than tacrine were synthesized [55] (Figure 6). Their activity in vitro on AChE and BuChE showed inhibitory ability in $\mu \mathrm{M}$ scale.

Figure 6. $N$-Alkyl-7-MEOTA hydrochlorides 16a-n.<smiles>[R]Nc1c2c(nc3ccc(OC)cc13)CCCC2</smiles>

16a-n

$\mathrm{R}=\operatorname{alkyl} \mathrm{C}_{2}-\mathrm{C}_{15}$.

The inhibitory ability and selectivity index for $h \mathrm{AChE}$ of new compounds were compared to standards of THA, 7-MEOTA. Compound 16e showed the best selectivity ratio for $\mathrm{AChE}\left(\mathrm{IC}_{50}=0.10 \mu \mathrm{M}\right.$, which is five more potent than THA). The docking with compound 5 showed that the 7-MEOTA moiety was bound and the active gorge between Trp86 and Tyr337 by $\pi-\pi$ stacking in the PAS anionic aromatic site. 


\subsubsection{Dual binding tacrine inhibitors}

\subsubsection{Bis-tacrine ligands}

About ten years ago, bis(7)-tacrine analogues linked by an alkylene chain (bis(n)-cognitin) were prepared and it was proved that these dimeric molecules of tacrine offered a much stronger potency and selectivity towards AChE [56]. Bis(7)-tacrine possessed a multi-target effect including inhibition of AChE, NMDA receptors and nitric oxide synthase signaling [57]. Bis(7)-tacrine simultaneously binds at both the ACS and the PAS. This dimeric analogue provides a higher selectivity towards AChE over BuChE. Unfortunately, THA is not without serious toxicity, so it would be logical to develop more potent and selective inhibitors for AChE inhibition which would be similar to THA.

The synthesis of several homodimeric tacrine-based AChE inhibitors was reported [56,57], the increased inhibitory potency and target specificity of which was the result of the simultaneous binding of the units to the active and peripheral anionic sites of AChE. Consequently, tacrine homobivalent ligands could be promising drug candidates for the treatment of AD. In the search for highly selective and potent derivatives of tacrine (1), a number of homodimeric tacrine congeners were synthesized and tested for their effects on acetylcholinesterase $(\mathrm{AChE})$ and butyrylcholinesterase $(\mathrm{BuChE})$ inhibitions.

A series of bifunctional AChE inhibitor analogs of tacrine, linked with alkylene tethers $\mathbf{1 7}$, were synthesized (Figure 7). Their ability to interact with the catalytic and peripheral sites of AChE has been confirmed [58-60].

Figure 7. Homotacrine ligands analogs 17.

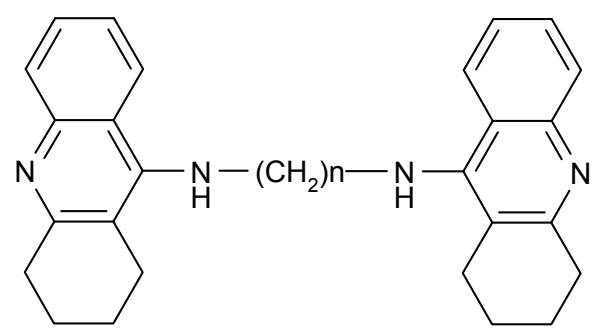

17

17a-i, $\mathbf{k}: \mathbf{n}=2-10,12$.

Concerning the inhibition effect of the synthesized compounds toward $\mathrm{AChE}$ and BuChE, it was found that the heptylene-linked dimmer $\mathbf{1 7} \mathbf{f}$ shows the optimum potential activity related to the length of the alkylene chain $\left(\mathrm{IC}_{50}=0.40 \pm 0.025 \mathrm{nM}, \mathrm{IC}_{50} \mathrm{BuChE} / \mathrm{IC}_{50} \mathrm{AChE}=980\right)$ in comparison with THA [56].

Also of interest is the investigation of Carlier et al. [60] using bis-hydrochloride salts of the previously mentioned bases 17 in the series of ammonia, dimethylamine, 4-aminopyridine, 4aminoquinoline, and tacrine. The compounds follow trends in $\mathrm{IC}_{50}$ values regarding their calculated desolvatation free energies $\Delta \Delta \mathrm{G}_{\text {theor }}$ in water/vacuum, and suggest the importance of ligand hydrophobicity for cation- $\pi$ interaction with peripheral sites.

Following on from the above mentioned problems, Savini et al. synthesized a new series of homodimeric tacrine analogs 19 (Figure 8), which are characterised by a different length and character of the tether [61]. The most potent AChEI was homodimer 6,8-dichlorotacrine 19a. 
Figure 8. 9-Amino-6,8-dichloro-1,2,3,4-tetrahydroacridine 18, homotacrine hybrids 19.<smiles>Nc1c2c(nc3cc(Cl)cc(Cl)c13)CCCC2</smiles>

18

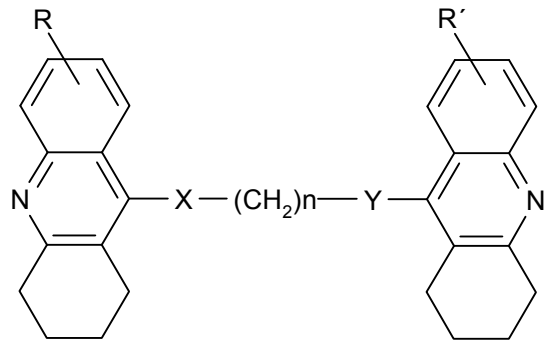

19

19a: $\mathrm{n}=7 ; \mathrm{X}, \mathrm{Y}=\mathrm{NH} ; \mathrm{R}, \mathrm{R}^{\prime}=6,8-\operatorname{diCl} ; \mathbf{1 9 b}: \mathrm{n}=7 ; \mathrm{X}, \mathrm{Y}=\mathrm{S} ; \mathrm{R}, \mathrm{R},=\mathrm{H}$.

The congeners of tacrine-tacrine homodimers with 6-8 methylene units 20-22 (Figure 9) were observed by $\mathrm{Hu}$ and his colleagues [62]. Their studies integrated previous findings to carry out changes in carbocyclic ring size on the 6-substituted position and isosteric modification toward enhanced optimization for AChE inhibition potency.

Figure 9. Bis-tacrine congeners 20-22.

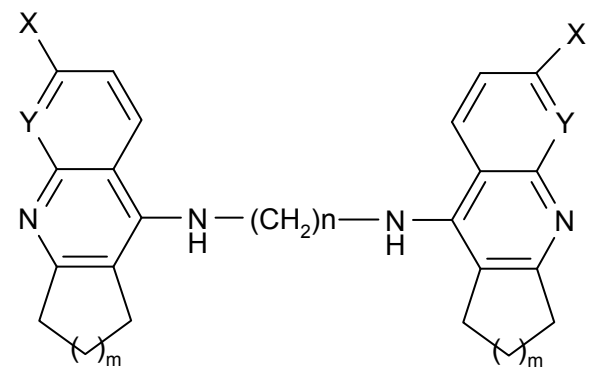

20-22

\begin{tabular}{lllll}
\hline & $\mathbf{X}$ & $\mathbf{Y}$ & $\mathbf{m}$ & $\mathbf{n}$ \\
\hline $\mathbf{2 0 a}-\mathbf{c}$ & $\mathrm{H}$ & $\mathrm{CH}$ & 1 & $6,7.8$ \\
$\mathbf{2 1 a}-\mathbf{c}$ & $\mathrm{H}$ & $\mathrm{CH}$ & 2 & $6,7,8$ \\
$\mathbf{2 1 d}-\mathbf{f}$ & $\mathrm{F}$ & $\mathrm{CH}$ & 2 & $6,7,8$ \\
$\mathbf{2 1 g}-\mathbf{i}$ & $\mathrm{Cl}$ & $\mathrm{CH}$ & 2 & $6,7,8$ \\
$\mathbf{2 1 j}-\mathbf{m}$ & $\mathrm{H}$ & $\mathrm{N}$ & 2 & $6,7,8$ \\
$\mathbf{2 2 a}-\mathbf{c}$ & $\mathrm{H}$ & $\mathrm{CH}$ & 3 & $6,7,8$ \\
\hline
\end{tabular}

The work describes in detail the influence of various structural changes, such as the size of the carbocyclic ring $\mathbf{2 1 a}-\mathbf{m}, \mathbf{2 2 a}-\mathbf{c}$, incorporation of a halogen at the 6-position of homodimeric tacrines 21d-i, insertion of an aza into the tacrine nucleus $\mathbf{2 1} \mathbf{j}-\mathbf{m}$ and the length of tether inhibition potency of $\mathrm{AChE}$ and BuChE. The homodimeric congeners, heptylene-linked bis-(6-chloro)-tacrine 21h showed much improved potency and selectivity of $\mathrm{AChE}\left(\mathrm{IC}_{50}=0.07 \mathrm{nM}, \mathrm{BuChE} / \mathrm{AChE}=371\right)$.

\subsubsection{Heterotacrine ligands}

A great attention was dedicated to new AChEI compounds, with dual binding mode of action, which bear a tacrine-related unit for interaction with the active site, either at the mid-gorge and 
peripheral site. These hybrid molecules were potent and selective inhibitors of human AChE, and they were able to interfere with both formation and amyloid aggregation of the $A \beta$ peptide. A number of $\mathrm{AChE}$ inhibitors have been identified in plant extracts, and one of them is Huperzine A. Hybrid molecules of tacrine with Huperzine A had been designed and studied during the last decade. Several hybrid molecules of tacrine with Huperzine A were prepared by Badia et al. [63] and Camps et al. [64,65], and some of them were more active than tacrine.

Donepezil as a well known drug in the treatment of $\mathrm{AD}$, and is still the focus of research to find new potent AChE inhibitors. In this context, Shao et al. [66] prepared novel tacrine-donepezil hybrids as dual binding side AChE inhibitors. Both hybrids 23 and 24 (Figure 10) were found to be more potent for AChE inhibition than tacrine.

Figure10. Tacrine-donepezil hybrids 23, 24.

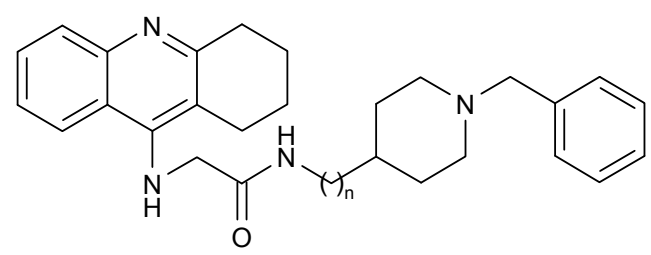

23, 24

23: $\mathrm{n}=2 ; 24: \mathrm{n}=1$.

In vitro $\mathrm{AChE}$ and $\mathrm{BuChE}$ inhibitory activities of the hybrids 23 and $\mathbf{2 4}$ were $\mathrm{IC}_{50}=6.0 \mathrm{nM}$, $\mathrm{IC}_{50}=10.2 \mathrm{nM}$, respectively.

Another paper concerning the above mentioned topic of donepezil-tacrine hybrids 25-28 was published by Camp et al. [67], in which the hybrids were seen to interact simultaneously with the active, peripheral and midgorge binding sites of AChE (Figure 11). These compounds contain 5,6-dimethoxy-2-[(4-piperidinyl)methyl]-1-indanone moiety of donepezil with tacrine or 6-chlorotacrine as congeners, and have been tested for their ability to inhibit AChE and BuChE.

Figure 11. Tacrine-donepezil hybrids 25-28.

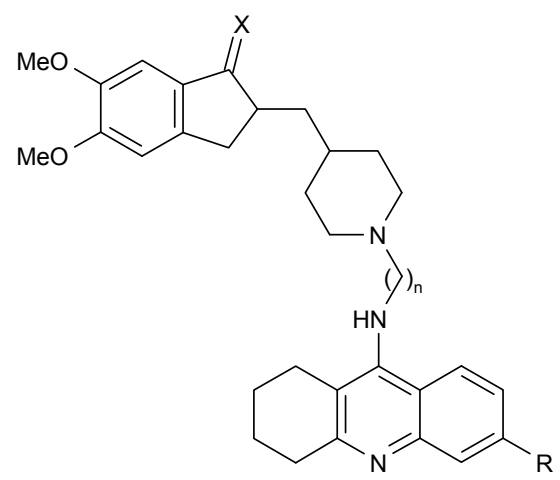

25-28

25.2HCl: a, $\mathrm{X}=\mathrm{O}, \mathrm{R}=\mathrm{H}, \mathrm{n}=2 ; \mathbf{b}, \mathrm{X}=\mathrm{O}, \mathrm{R}=\mathrm{H}, \mathrm{n}=3 ; \mathbf{2 6} .2 \mathrm{HCl}$ : $\mathbf{a}, \mathrm{X}=\mathrm{O}, \mathrm{R}=\mathrm{Cl}, \mathrm{n}=2 ; \mathbf{b}, \mathrm{X}=\mathrm{O}$,

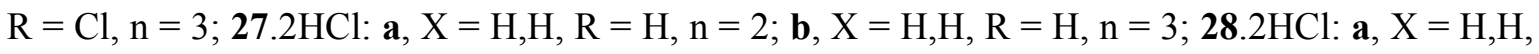
$\mathrm{R}=\mathrm{Cl}, \mathrm{n}=2 ; \mathbf{b}, \mathrm{X}=\mathrm{H}, \mathrm{H}, \mathrm{R}=\mathrm{Cl}, \mathrm{n}=3$. 
The highly potent compound $\mathbf{2 6} \mathbf{b}$ bearing an indanone unit chlorine atom at the tacrine unit and a tether length of three methylenes were tested against bovine and human $\mathrm{AChEs}$ and exhibited $\mathrm{IC}_{50}$ values in the subnanomolar range.

Novel bivalent tacrine/acridine cholinesterase inhibitors (29-32, 33a-c, 34, Figure 12) showing dual binding affinity toward $\mathrm{AChE}$ and $\mathrm{BuChE}$ were synthesized using 9-chlorotetrahydroacridine, 9-chloroacridine, 6,9-dichloro-2-methoxyacridine and 9-isothiocyanatotacrine as synthons. Their neuroprotective activity against $h \mathrm{AChE}$ and $h \mathrm{BuChE}$ reached nanomolar concentrations [68-70].

Figure 12. Heterodimeric tacrine/acridine hybrids 29-34.

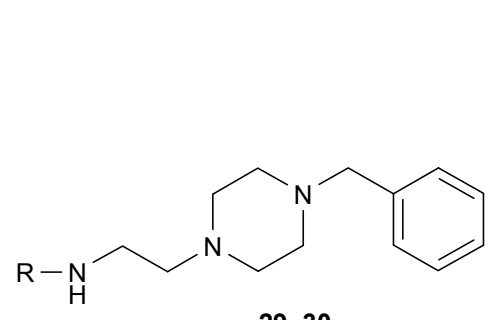

29,30<smiles>[R]NCCN1CCN(c2c3ccccc3nc3ccccc23)CC1</smiles>

31<smiles>[R]NCCN1CCN(c2c3c(nc4ccccc24)CCCC3)CC1</smiles>

32<smiles>S=C(Nc1c2c(nc3ccccc13)CCCC2)Nc1c2c(nc3ccccc13)CCCC2</smiles>

33a-c<smiles>COc1ccc2nc3cc(Cl)ccc3c(NCCN3CCNCC3)c2c1</smiles>

34

29, 31: $\mathrm{R}=$ 1,2,3,4-tetrahydroacridin-9-yl; 30, 32: $\mathrm{R}=$ 2-methoxy-6-chloroacridin-9-yl; 33a-c: $\mathrm{n}=2,4,6$

A new series of donepezil-tacrine hybrid derivatives 35-40 and 41-46 (Figure 13) combining a tacrine, 6-chlorotacrine or acridine unit were synthesized by Alonso et al. [71]. These derivatives obtained a tacrine heterocyclic ring as AChEI and indanone or relative heterocycles responsible for the binding to the peripheral site of the enzyme.

Figure 13. Tacrine-donepezil hybrids $35-40$ and $\mathbf{4 1 - 4 6 .}$
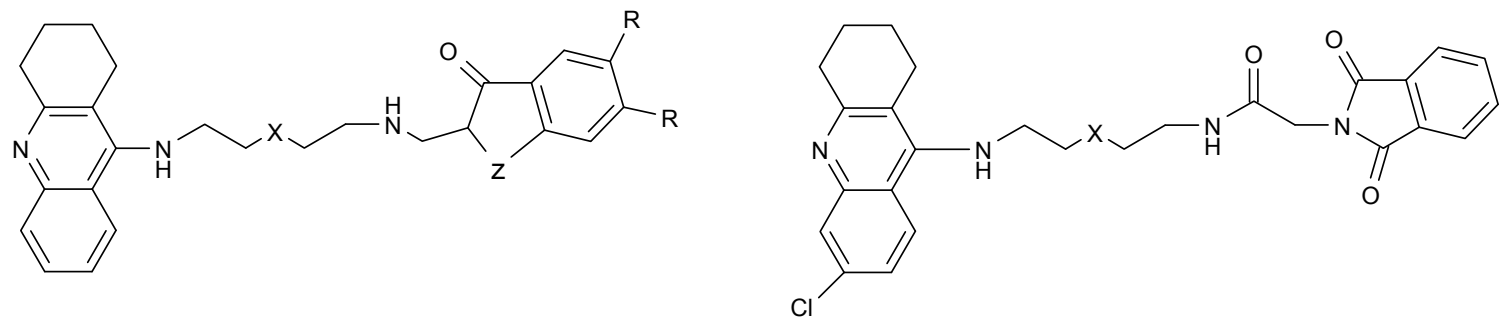

35-40

35: $\mathrm{Z}=\mathrm{H}, \mathrm{R}=\mathrm{OMe}, \mathrm{X}=\left(\mathrm{CH}_{2}\right)_{2} ; 36: \mathrm{Z}=\mathrm{H}, \mathrm{R}=\mathrm{OMe}, \mathrm{X}=\left(\mathrm{CH}_{2}\right)_{3} ; 37: \mathrm{Z}=\mathrm{CO}, \mathrm{R}=\mathrm{H}, \mathrm{X}=\left(\mathrm{CH}_{2}\right)_{2}$; 38: $\mathrm{X}=\left(\mathrm{CH}_{2}\right)_{2} ;$ 39: $\mathrm{X}=\left(\mathrm{CH}_{2}\right)_{3} ; \mathbf{4 0}: \mathrm{X}=\mathrm{CH}_{3} \mathrm{~N}\left(\mathrm{CH}_{2}\right)_{2}$. 
Figure 13. Cont.

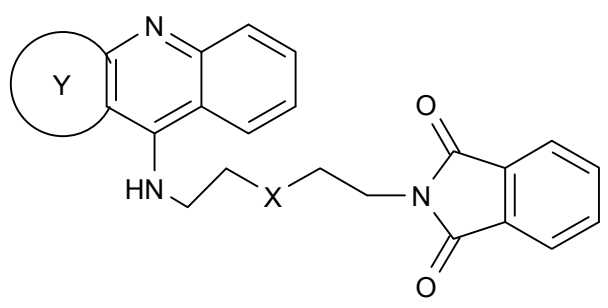

41-46

41: $\mathrm{X}=\left(\mathrm{CH}_{2}\right)_{3}, \mathrm{Y}=\mathrm{C}_{4} \mathrm{H}_{8} ; 42: \mathrm{X}=\left(\mathrm{CH}_{2}\right)_{4}, \mathrm{Y}=\mathrm{C}_{4} \mathrm{H}_{8} ; 43: \mathrm{X}=\left(\mathrm{CH}_{2}\right)_{2}, \mathrm{Y}=\mathrm{C}_{4} \mathrm{H}_{4} ; 44: \mathrm{X}=\left(\mathrm{CH}_{2}\right)_{3}$, $\mathrm{Y}=\mathrm{C}_{4} \mathrm{H}_{4} ; 45: \mathrm{X}=\left(\mathrm{CH}_{2}\right)_{4}, \mathrm{Y}=\mathrm{C}_{4} \mathrm{H}_{4} ; 46: \mathrm{X}=\left(\mathrm{CH}_{2}\right)_{5}, \mathrm{Y}=\mathrm{C}_{4} \mathrm{H}_{4}$.

These derivatives are able to bind simultaneously to both sites of the enzyme. A propidium competition assay confirms the interaction of the compounds 35-46 at the PAS of AChE. Compounds $40\left(\mathrm{IC}_{50}=2.8 \mathrm{nM}\right)$, and $46\left(\mathrm{IC}_{50}=2.4 \mathrm{nM}\right)$ were found to be the most potent AChEI, while tether length for the linker seemed to be 9 (compound 46) or 10 (compound 40). The most active AChEIs discovered to date are represented by a large series of novel tacrine-indole heteroligands 47-69 synthesized by Muñoz-Ruiz [72] and his colleagues (Figure 14). The dual binding mode of the compounds under study takes place at both the catalytic and peripheral sites of the enzyme.

Figure 14. Tacrine-indole heteroligands 47-69.

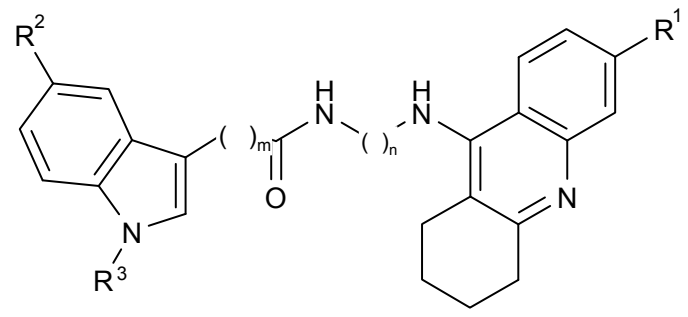

$47-62$

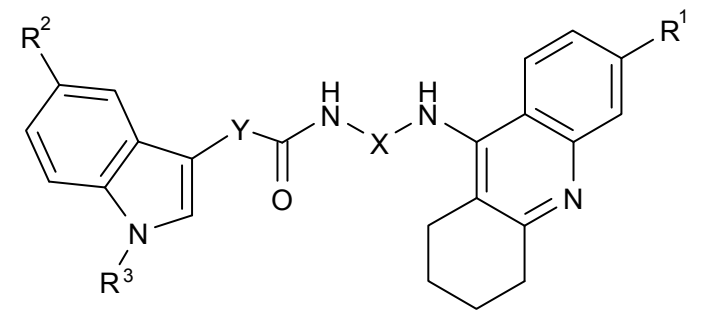

63-69

\begin{tabular}{cccccc}
\hline & $\mathbf{R}^{\mathbf{1}}$ & $\mathbf{R}^{\mathbf{2}}$ & $\mathbf{R}^{\mathbf{3}}$ & $\mathbf{n}$ & $\mathbf{m}$ \\
\hline $\mathbf{4 7}$ & $\mathrm{H}$ & $\mathrm{H}$ & $\mathrm{H}$ & $\left(\mathrm{CH}_{2}\right)_{5}$ & $\left(\mathrm{CH}_{2}\right)_{2}$ \\
$\mathbf{4 8 - 5 3}$ & $\mathrm{Cl}$ & $\mathrm{H}$ & $\mathrm{H}$ & $\left(\mathrm{CH}_{2}\right)_{5-10}$ & $\left(\mathrm{CH}_{2}\right)_{2}$ \\
$\mathbf{5 4 - 5 8}$ & $\mathrm{Cl}$ & $\mathrm{H}$ & $\mathrm{H}$ & $\left(\mathrm{CH}_{2}\right)_{5-8}$ & - \\
$\mathbf{5 9}$ & $\mathrm{Cl}$ & $\mathrm{Br}$ & $\mathrm{H}$ & $\left(\mathrm{CH}_{2}\right)_{7}$ & $\mathrm{CH}_{2}$ \\
$\mathbf{6 0 , 6 1}$ & $\mathrm{Cl}$ & $\mathrm{H}$ & $\mathrm{H}$ & $\left(\mathrm{CH}_{2}\right)_{5,6}$ & $\left(\mathrm{CH}_{2}\right)_{3}$ \\
$\mathbf{6 2}$ & $\mathrm{Cl}$ & $\mathrm{H}$ & $\mathrm{Me}$ & $\left(\mathrm{CH}_{2}\right)_{7}$ & - \\
$\mathbf{6 3}$ & $\mathrm{H}$ & $\mathrm{H}$ & $\mathrm{H}$ & $\left(\mathrm{CH}_{2}\right)_{3} \mathrm{NMe}_{\left(\mathrm{CH}_{2}\right)_{3}}$ & $\left(\mathrm{CH}_{2}\right)_{2}$ \\
$\mathbf{6 4}$ & $\mathrm{Cl}$ & $\mathrm{H}$ & $\mathrm{H}$ & $\left(\mathrm{CH}_{2}\right)_{3} \mathrm{NMe}_{\left(\mathrm{CH}_{2}\right)_{3}}$ & $\left(\mathrm{CH}_{2}\right)_{2}$ \\
$\mathbf{6 5}$ & $\mathrm{Cl}$ & $\mathrm{CN}$ & $\mathrm{H}$ & $\left(\mathrm{CH}_{2}\right)_{6}$ & $\left(\mathrm{CH}_{2}\right)_{2}$ \\
$\mathbf{6 6}$ & $\mathrm{Cl}$ & $\mathrm{H}$ & $\mathrm{H}$ & $\left(\mathrm{CH}_{2}\right)_{6}$ & $\mathrm{CH} \mathrm{CH}$ \\
$\mathbf{6 7 - 6 9}$ & $\mathrm{Cl}$ & $\mathrm{H}$ & $\mathrm{H}$ & $\left(\mathrm{CH}_{2}\right)_{5-7}$ & $\left(\mathrm{CH}_{2}\right)_{2} \mathrm{O}$ \\
\hline
\end{tabular}

The highest AChE inhibition activity was shown by hetrodimers 49 and 50, bearing two methylene groups between the indole ring and the amide functionality and the tether length from the amide to the tacrine unit bearing 6 or 7 methylenes $\left(\mathbf{4 9}\right.$ : $\mathrm{IC}_{50}=70 \mathrm{pM}$; 50: $\left.\mathrm{IC}_{50}=20 \mathrm{pM}\right)$. 
The next interesting series of heterotacrine ligands as AChEIs containing peptidic tethers and one or two tacrine skeletons (70a-j) were synthesized [39] by Butini (Figure 15). The individual sections of the studied compounds were coupled with natural or unnatural L-amino acids, hydrophobic in nature, chosen on the basis of adaptability to the cleft (L-glutamate and L-proline). The compounds containing tryptophane units $\mathbf{7 0 \mathbf { i }}$ and $\mathbf{7 0 \mathbf { j }}$ are more potent and selective $h$ BuChEIs $\left(\mathrm{IC}_{50}=1.87 \mathrm{nM} ; \mathrm{IC}_{50}=1.33 \mathrm{nM}\right.$, respectively).

Figure 15. Tacrine heteroligands containing peptidic tethers $\mathbf{7 0 a}-\mathbf{j}$.<smiles>[R]C[C@@H](N)C(=O)NNC(=O)Nc1c2c(nc3ccccc13)CCCC2</smiles>

70a-c, e-h<smiles>O=C(CNC(=O)[C@H]1Cc2ccccc2CN1)Nc1c2c(nc3ccccc13)CCCC2</smiles><smiles>[R]C[C@@H](N)C(=O)NCCNc1c2c(nc3ccccc13)CCCC2</smiles>

70i, $\mathbf{j}$

70d

\begin{tabular}{|c|c|c|c|c|c|c|c|c|c|}
\hline 70 & $\mathbf{a}$ & b & c & $\mathbf{e}$ & $\mathbf{f}$ & g & $\mathbf{h}$ & i & $\mathbf{j}$ \\
\hline $\mathbf{n}$ & 1 & 1 & 1 & 1 & 1 & 2 & 2 & & \\
\hline $\mathbf{R}$ & $\mathrm{H}$ & $\mathrm{Me}$ & $\mathrm{H}$ & $\mathrm{H}$ & $\mathrm{Me}$ & Boc & $\mathrm{H}$ & Boc & $\mathrm{H}$ \\
\hline
\end{tabular}

New hybrids of compounds consisting of tacrine or 6-chlorotacrine units as the active sites of interacting moiety, either the 5,6-dimethoxy-2-[(4-piperidinyl)methyl]-1-indanone fragment of donepezil, or a 5-phenylpyrano[3,2-c]quinoline system, as the peripheral site interacting unit (Figure 16) 71-80 were reported [64]. All of the studied compounds demonstrate more potent AChEI than tacrine; 6-chlorotacrine and donepezil the best of the synthesized compounds are 81-88 $\left(\mathrm{IC}_{50}=14.4-19.2 \mathrm{nM}\right)$. A possible binding mode of studied ligands can be explained by molecular docking studies.

In order to obtain novel inhibitors of $\mathrm{AChE}$ and $\mathrm{BuChE}$, a series of heterodimer derivatives 81, 82, in which the tacrine moiety was connected to the trimetoxybenzene unit through a hydrazide-based linker of varying length were synthesized by Elsinghorst [73] (Figure 17).

From the data retrieved for acetylcholinesterase, a comparison of the corresponding derivatives of both series revealed that in most cases compounds $\mathbf{8 1}$ were superior to compounds $\mathbf{8 2}$. It was proved that the most potent heterodimeric inhibitors contain an 11 - or 12 -atoms spacer $\left(\mathbf{8 1} \mathbf{h}, \mathrm{IC}_{50}=3.25 \mathrm{nM}\right.$; $\left.\mathbf{8 1 i}, \mathrm{IC}_{50}=2.73 \mathrm{nM}\right)$. In the case of the other series, 82f, with a total spacer length of 11 atoms ligand, seems to be the best inhibitor. 
Figure 16. Heterotacrine-quinoline hybrids 71-80.<smiles>[Y]NC(=O)Nc1c2c(nc3cc(Cl)ccc13)CCCC2</smiles>

71-80

71-75.2HCl: $\mathrm{n}=0, \mathrm{n}^{\prime}=6-10, \mathrm{R}^{1}=\mathrm{Cl} ; \mathbf{7 6}-\mathbf{8 0} .2 \mathrm{HCl}: \mathrm{n}=2, \mathrm{n}^{\prime}=4-8, \mathrm{R}^{1}=\mathrm{H}$.

Figure 17. Trimethoxybenzene-tacrine hybrids 81 and $\mathbf{8 2}$.<smiles>COC(=O)C(=Cc1cc(OC)c(OC)c(OC)c1)NNc1c2c(nc3ccccc13)CCCC2</smiles><smiles>COc1cc(CC(=O)NCC(=O)NNc2c3c(nc4ccccc24)CCCC3)cc(OC)c1OC</smiles>

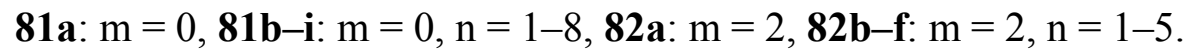

\subsubsection{Multifunctional tacrine ligands}

In recent years, several works concerning active research into multifunctional agents with different complementary biological activities to $\mathrm{AD}$ have been published. Novel multifunctional compounds 83-99 with antioxidant, metal-binding properties, inhibition of $A \beta$ aggregation and dual inhibition of $\mathrm{AChE} / \mathrm{BuChE}$ have been designed and synthesized by Fernández-Bachiller et al. [74] (Figure 18). These tacrine-8-hydroxyquinoline (PBT2) hybrids show excellent inhibition activity against $h \mathrm{AChE}$ and $h B u C h E$ at nanomolar and subnanomolar concentrations. The most active derivative was compound 86 which contains unsubstituted 8-hydroxyquinoline fragment and a methylene tether of $7-10$ carbons $\left(\mathrm{IC}_{50}=20 \mathrm{nM}\right)$. Three of the synthesized compounds 86, 90,94 were chosen for evaluation due to their characteristics as free radical scavengers, their antioxidant activities and their inhibition of $A \beta$ aggregation. 
Figure 18. Heterodimeric tacrine-quinoline derivatives 83-99.

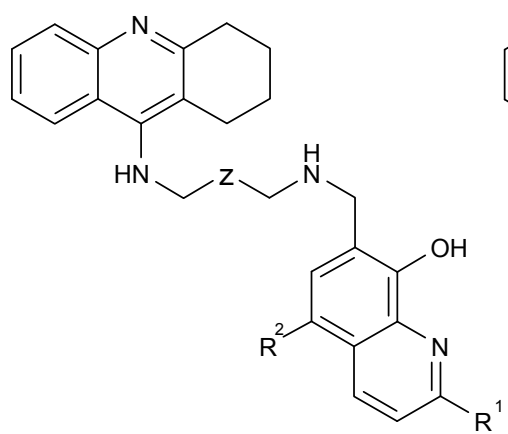

83-96

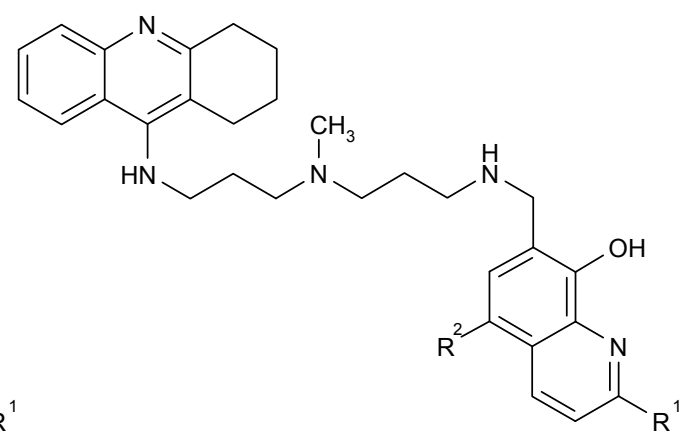

97-99

83-88: $\mathrm{R}^{1}, \mathrm{R}^{2}=\mathrm{H}, \mathrm{Z}=\left(\mathrm{CH}_{2}\right)_{4-8,10} ;$ 89-92: $\mathrm{R}^{1}=\mathrm{CH}_{3}, \mathrm{R}^{2}=\mathrm{H}, \mathrm{Z}=\left(\mathrm{CH}_{2}\right)_{5-8} ;$ 93-96: $\mathrm{R}^{1}=\mathrm{H}$, $\mathrm{R}^{2}=\mathrm{Cl}, \mathrm{Z}=\left(\mathrm{CH}_{2}\right)_{6-8,10} ;$ 97: $\mathrm{R}^{1}=\mathrm{H}, \mathrm{R}^{2}=\mathrm{H} ;$ 98: $\mathrm{R}^{1}=\mathrm{CH}_{3}, \mathrm{R}^{2}=\mathrm{H} ;$ 99: $\mathrm{R}^{1}=\mathrm{H}, \mathrm{R}^{2}=\mathrm{Cl}$.

Further interesting work has been dedicated to multifunctional compounds of bis-tacrine derivatives which simultaneously interact with catalytic and PAS of the enzyme, and which are able to inhibit $\mathrm{AChE}$ induced $\mathrm{A} \beta$ aggregation and acting as metal chelators (Bolognesi et al. [75]).

Figure 19. Multifunctional bis-tacrines 100-102.

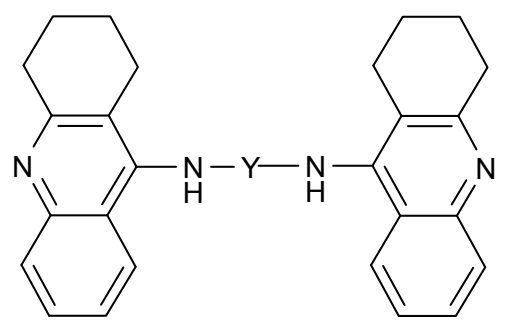

100-102

compound 100

All synthesized hybrids 100-102 show dramatically more potent inhibition of AChE than tacrine. To improve the hepatotoxicity of tacrine hybrids, novel amine and amide-linked nitrate- and NOatetacrine hybrids 103-116 (Figure 20) have been synthesized in connection with their ability to inhibit cholinesterases and for their vasorelaxation effects [76]. The most active target compounds were 108, 111 with high AChEI $\left(\mathrm{IC}_{50}=6.4 \mathrm{nM}, 5.6 \mathrm{nM}\right)$ and $\mathrm{BuChE}\left(\mathrm{IC}_{50}=5.5 \mathrm{nM}, 9.9 \mathrm{nM}\right)$.

A new series of tacrine-ferulic acid hybrids $117 \mathbf{a}-\mathbf{e}$ with antioxidant effects have been synthesized and tested as multipotent anti-Alzheimer drug analogs by Fang et al. [77] (Figure 21). Among all of the tested hybrids $\mathbf{1 1 7 a}-\mathbf{e}$, ligand $\mathbf{1 1 7 d}$ showed a greater activity toward $\mathrm{AChE} / \mathrm{BuChE}$ $\left(\mathrm{IC}_{50}=4.4 \mathrm{nM}, 6.7 \mathrm{nM}\right.$, resp.) in comparison to tacrine. The optimal differences between the tacrinelike heterocycle and the ferulic acid moiety were 6-7 atoms long. 
Figure 20. NO-donor-tacrine hybrids 103-116.<smiles>[NH]CNC(=O)[N+]([O-])O[Na]</smiles>

103, 104: $m=3, n=1,2$ 105, 106: $m=4, n=1,2$

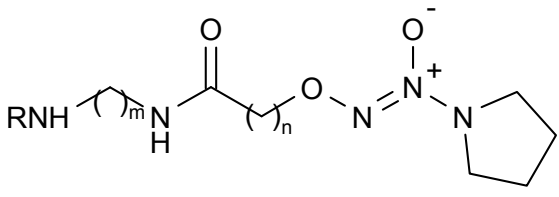

113, 114: $m=3,4, n=1$<smiles></smiles>

107-109: $\mathrm{m}=3, \mathrm{o}=2,3,6$ 110-112: $m=4, o=2,3,6$<smiles>CC(C)(CO[N+](=O)[O-])C(=O)NCN</smiles>

115, 116: $\mathrm{m}=3,4$

$\mathbf{R}=$<smiles>Cc1c2c(nc3ccccc13)CCCC2</smiles>

Figure 21. Tacrine-ferulic acid hybrids 117a-e.<smiles>COc1cc(/C=C/C(=O)CCNc2c3c(nc4ccccc24)CCCC3)ccc1O</smiles>

$$
117 \mathbf{a}-\mathbf{e}, \mathrm{n}=2-5,8 \text {. }
$$

To improve aqueous solubilities of tacrine ligands in pharmacological testing, a novel series of AChEIs 118-121 bearing tacrine pharmacophore and two different $\mathrm{CB}_{1}$ antagonistic pharmacophores with a polar group or ionizable nitrogen atom have been synthesized; 118 and 119 contain pyrazoline rings, while 120 and 121 contain imidazole rings (Figure 22) [78].

Figure 22. Tacrine- $\mathrm{CB}_{1}$ receptor antagonists 118-121.
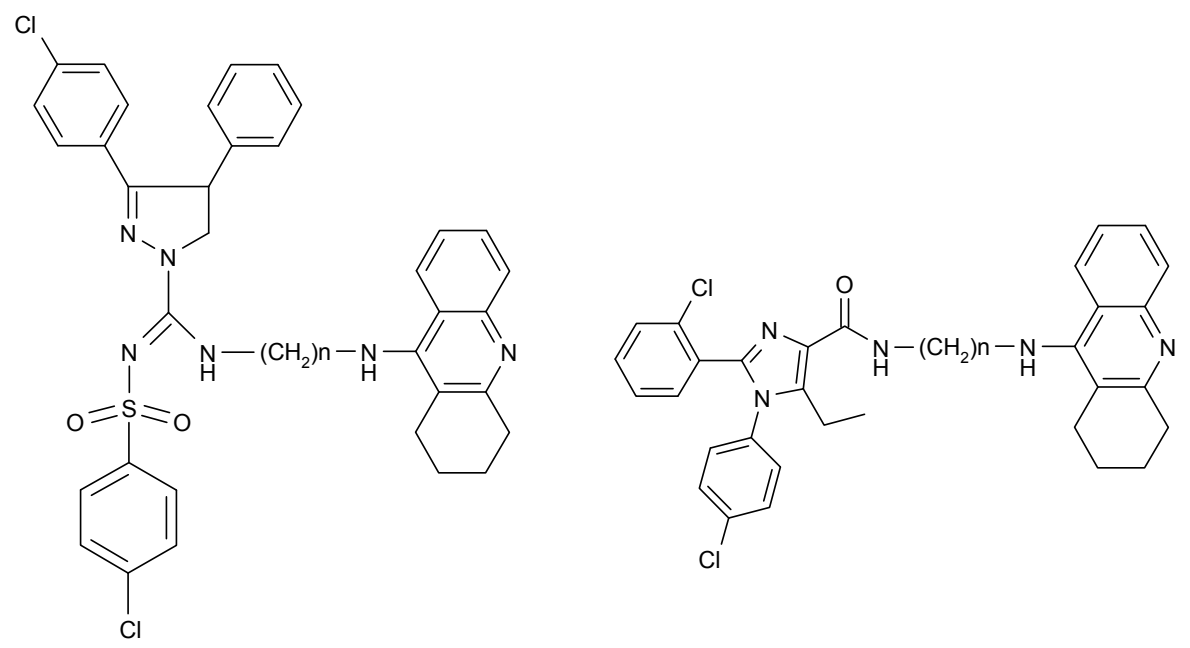

118, 119: $\mathrm{n}=4,7 ; \mathbf{1 2 0}, 121: \mathrm{n}=4,7$. 
The imidazole derivative $\mathbf{1 2 0}$ with spacer length $\mathrm{n}=4$ showed high $\mathrm{CB}_{1}$ receptor affinity $(48 \mathrm{nM})$ and demonstrated AChE inhibitory activity at the same potency as tacrine.

Marco-Contelles [79] have published their results on the synthesis of novel multipotent tacrine-1,4dihydropyridine hybrids 123-131. The multipotent character of the compounds under study is concerned with their $\mathrm{AChE} / \mathrm{BuChE}$ inhibition, propidium iodide displacement, $\mathrm{Ca}^{2+}$ channel blockade, and neuroprotective activity (Figure 23).

Figure 23. Tacrine-1,4-dihydropyridine hybrids 123-131.

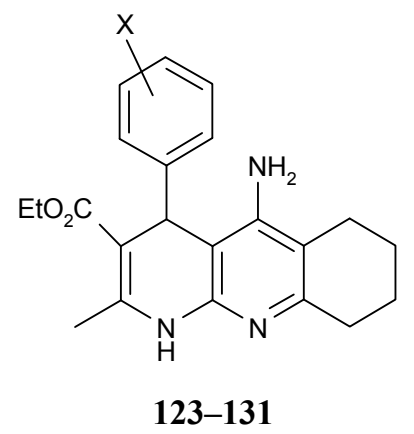

123: $\mathrm{X}=\mathrm{H}$; 124: $\mathrm{X}=4-\mathrm{F}$; 125: $\mathrm{X}=2-\mathrm{NO}_{2} ;$ 126: $\mathrm{X}=3-\mathrm{NO}_{2} ; 127: \mathrm{X}=4-\mathrm{NO}_{2} ; 128: \mathrm{X}=4-\mathrm{Me}$; 129: $X=2-\mathrm{MeO} ; 130: X=3-\mathrm{MeO} ; 131: X=4-\mathrm{MeO}$.

Their results confirm that compounds 123-131 are very selective and potent AChEIs and that they show outstanding neuroprotective profiles and a moderate $\mathrm{Ca}^{2+}$ channel blockade effect.

\section{Tacrine and Anti-Amyloid Aggregation}

Amyloid aggregation of proteins is a complex process associated with amyloid-related neurodegenerative disorders such as Alzheimer's and prion diseases. The conversion of a specific protein or protein fragment from soluble native states into amyloid aggregates results in the formation of amyloid deposits with a single predominant protein compound characteristic of each disease. In AD, two types of aggregates have been identified in the brain: intracellular neurofibrillary tangles created by tau protein and extracellular senile plaques NFTs consisting of A $\beta$ peptide. Tau protein is also involved in various tauopathies. The fibrillar form of huntingtin is associated with Huntington's disease, and transthyretin with familial amyloid polyneuropathy. Amyloid deposits formed by alpha-synuclein are found in patients with Parkinson's disease [80].

The formation of amyloid aggregates is triggered by nucleation-dependent polymerization from subunit protein by axial stacking of beta strands, generating a cross-beta-sheet structure at the core of the filaments [81]. The process of aggregation involves a series of steps during which many intermediate aggregation states are populated. Recent evidence points to these intermediate states as the toxic moieties primarily responsible for cell damage or cell death, which are critical steps in the origin and progression of amyloid-related neurodegenerative disorders [82]. Recently, growing evidence has emerged that soluble oligomers may be the main toxic species $[83,84]$. The reason why early aggregates are more toxic than mature amyloid fibrils is not yet clear, although it is likely that it arises from the accessibility of oligomers to interact inappropriately with cellular species leading to deregulation of cell homeostasis [85-87]. 
Currently, the precise mechanisms of toxicity have not been fully elucidated; however, there is evidence that reduction of amyloid deposits lead to alleviation of disease's symptoms [88,89]. As a consequence, considerable effort has been directed toward the identification of the substances able to reduce amyloid aggregation. In the past few years, a range of diverse small molecules have been found to inhibit or reduce the amyloid aggregation of various proteins, particularly in relation to $\mathrm{A} \beta$ deposition, the aggregation of transthyretin and the formation of protease-resistant forms of the prion protein [90-94]. Kim [93] investigated the effect of several classes of naturally occurring compounds on $\mathrm{A} \beta$ amyloid aggregation. The results of his study showed that curcumins, flavones type flavonoids, and naphthoquinones are potent inhibitors of $\mathrm{A} \beta$ fibrillization formation in vitro. Doplhin et al. [94] demonstrated that longer trioxime oligomers showed an effective reduction of $A \beta$ amyloid fibrils formation. One of the first compounds to be identified with blocked tau-tau interaction was the phenothiazine methylene blue [95]. This compound was shown to partially disrupt the structure of isolated paired helical filaments and could affect tau fibrillization. Interestingly, this dye molecule has now progressed into clinical testing in AD patients [96]. In a screen of 42 compounds, Taniguchi et al. [97] identified small molecules categorized as phenothiazines, polyphenols and porphyrins which were able to inhibit tau amyloid polymerization. It was found that a number of anthraquinones were able to inhibit tau aggregate formation and could also induce disassembly of pre-formed tau fibrils. A similar effect was observed for cyanine dyes [98] and rhodamines [99].

Acridine-based compounds were identified as potent inhibitors of protease-resistant forms of prion protein [100]. Anti-scrapie activity, probably through inhibition of the formation of protease-resistant prion protein, has been found also for other acridine derivatives [92,101]. It has been shown that some acridines and bis-acridine derivatives are able to reduce scrapie prion concentration in infected cells [102]. The first acridine derivatives reported to inhibit or interact with the $\mathrm{A} \beta$ polymerization process are diaryl heterocyclic compounds and 9-acridone derivatives [103,104]. More recently, a high affinity for $\mathrm{A} \beta$ aggregation was detected for fluorinated acridine orange analogue $[105,106]$. The inhibiting activity was observed for acridine derivatives, namely for quinacrine and quinacrine mustard [107]. They have shown that these compounds are able to inhibit formation of amyloid fibrils of tau and $A \beta$ peptide.

The tacrine dimers 100-102 characterized by AChE inhibitory activities were tested for their ability to inhibit AChE-induced $\mathrm{A} \beta$ fibrillogenesis [75]. In particular, $100 \mu \mathrm{M}$ inhibitors inhibited $\mathrm{A} \beta$ aggregation from $53 \%$ to $76 \%, \mathbf{1 0 0}$ being the most potent and slightly more potent than $\mathbf{1 7 f}(76 \%$ compared to $68 \%$ ). These findings suggest that effective inhibitor concentration in the aggregation assay is much higher than the $\mathrm{IC}_{50}$ values in comparison to the enzyme. Muñoz-Ruiz et al. designed dual binding site acetylcholinesterase inhibitors as potent new drugs inhibiting amyloid $\mathrm{A} \beta$ peptide aggregation through binding to both catalytic and peripheral sites of the enzyme [72]. The heterodimers showing the best AChE inhibitory potency $(49,50$ and 58-60) were selected to assess their ability to inhibit $A \beta$ peptide $\left(A \beta_{1-40}\right)$ aggregation. Results showed that the heterodimers inhibited the $\mathrm{A} \beta$ peptide aggregation at $100 \mu \mathrm{M}$ in a range varying from $49 \%$ to $63 \%$, and that they were at least as potent as propidium, which caused $46 \%$ inhibitions. The most active compounds were 49 and $\mathbf{5 0}$, followed by 58, 59, 60 the latter being around 2-, 3- and 10-fold less active than the former compounds, respectively.

Hybrids 25-28 and 71-81 result in a significant in vitro ability to inhibit the $h$ AChE-induced aggregation of $\mathrm{A} \beta$ peptide, with these hybrids exhibiting percentages of inhibition of $23-46 \%$, 
38-66\%, respectively, at $100 \mu \mathrm{M}$. In the first series, the separation of two methylenes between the amido group of the linker and the pyrano[3,2-c] quinoline system leads to a higher $A \beta$ antiaggregating effect. In the second series, the substitution pattern leading to an optimal $A \beta$ antiaggregating effect involves the presence of an indane moiety irrespective of the length of the linker and the substitution at the tacrine unit. These results suggest that the new compounds could bind to the AChE-PAS and could therefore inhibit the $A \beta$ fibril formation promoted by this enzyme.

Recently, we have examined a small group of structurally distinct acridine derivatives which differ in molecule planarity and bulky side groups at the middle ring moiety for their ability to inhibit lysozyme fibril formation in vitro $[107,108]$. We have found that planar acridine compounds are very effective inhibitors, while spiroacridines have been ineffective in inhibiting fibril formation. Tetrahydroacridines have had no significant effect on the prevention of lysozyme fibrillization; moreover, in the presence of some derivatives, an enhanced degree of aggregation has been detected. Anti-amyloid activity has also been observed for glycosyl acridines [109]. The different activities of the acridine derivatives studied have indicated that the structure of the acridine side chains and planarity of the acridine cyclic core are the crucial elements in determining the extent of amyloid aggregation. The highest inhibiting activity among screened compounds at all was have been detected for dimeric acridine. A similar increase in anti-amyloid activity for bis-acridines was observed by May et al. [102]. They found that covalent acridine dimers could be more potent than monomeric equivalents in decreasing scrapie-prion concentration. Dolphin et al. [110] investigated the potential of a multimeric quinacrine derivative to inhibit $A \beta$ fibril formation in comparison to monomer quinacrine. The multimeric conjugate exhibits a cluster of four quinacrine derivatives on a rigid cyclopeptide core. Their data showed that the multimeric compound substantially enhanced inhibition of $A \beta$ polymerization into amyloid aggregates. It suggests that assembling multiple copies of acridine moieties to a central scaffold allows multiple interactions with protein leading to effective anti-amyloid activity of the compound.

\section{Neuroprotectivity of Tacrine}

The typical role of $\mathrm{AChE}$ is to terminate cholinergic neurotransmission, but $\mathrm{AChE}$ has also been observed in non-neuronal tissues (erythrocytes, megakaryocytes and the others), and there is significant evidence for additional noncatalytic functions of AChE. The level of this enzyme changes during proliferation, neurite growth, apoptosis, differentiation and also the expression of AChE is changed at neurodegenerative diseases [111-116]. Cholinergic neurons in brains affected by AD express more $\mathrm{AChE}$ than other neuron types and it has been confirmed that these neuronal cells have higher levels of AChE-S isoform. Apoptosis has been proposed to explain the loss of the cholinergic neurons but the exact mechanisms which regulate the expression of AChE during apoptosis have not been known. Recently, it has been confirmed that up-regulation of AChE-S is associated with activity of GSK-3 which plays a central role in ER-stress induced activation of caspase 3 [117]; as a result, the inhibition of caspases has been suggested as a therapeutic strategy in neurodegenerative diseases, although the possibility of caspase-independent death means that caspase inhibition can offer only transient protection. The search for new inhibitors of $\mathrm{AChE}$ has become more intense since $\mathrm{AChE}$ was characterized as a multifaceted protein, and also since the discovery of $\mathrm{AChE}$ in $\mathrm{AD}$ plaque formation and in the 
neurofibrillary tangles and the amyloid-positive vessels. Even when AChE-peptide was added at nanomolar concentrations, cells died via an apoptotic pathway [118-121]. In light of the non-classical role of AChE, AChEIs could act as multifunctional agents and some of them could possess neuroprotective effects in addition to their AChE-inhibiting action. Therefore the development of new AChEI, including derivatives of tacrine is aimed not only at improving selectivity for AChE and the better side effect profile/low cytotoxicity, but also the potency of their their neuroprotective [49,50,122-126]. Oxidative stress is an early event in AD pathogenesis and therefore new hybrid molecules of tacrine with antioxidant capacities are being synthesized and their neuroprotective effect studied. The neuroprotectivity of new derivatives of tacrine which inhibit $A \beta$ aggregation and the state of intracellular concentration of $\mathrm{Ca}^{2+}$ in neuronal tissue are also being researched.

\subsection{Hybrid Molecules of Tacrine and Oxidative Stress}

Increased oxidative stress resulting from free radical damage to cellular function can be involved in events leading to AD. New hybrid molecules of tacrine with antioxidants have been prepared to inhibit $\mathrm{AChE}$ and simultaneously to protect against oxidative stress. In addition, the hepatotoxicity of tacrine was confirmed and this issue could be reduced through the use of hybrid molecules of tacrine with antioxidant effects. Such types of bi-functional molecules, tacrine-8-hydroxyquinoline hybrids have recently been synthesized by Fernandez-Bachiller et al. [74]. As mentioned above, 8-hydroxyquinoline derivative is known antioxidant acting through the complexation of redox-active metals. These novel hybrid molecules at nano- and subnanomolar concentrations inhibited AChE, and they could be able to inhibit A $\beta$ aggregation promoted by $\mathrm{AChE}$. It was shown that tacrine-8-hydroxyquinoline hybrids possessed better antioxidant properties than Trolox and showed low cytotoxicity. Rodrigues-Franco et al. [127] and Fernandez-Bachiller et al. [128] used melatonin for the preparation of new hybrid molecules of tacrine. These hybrids were selective inhibitors of human AChE and they exhibited antioxidant capacities. Fang et al. [77] synthesized tacrine-ferulic acid hybrid and demonstrated that the cytotoxicity of this hybrid molecule was significantly decreased.

In neuronal cells, NO controls the release of neurotransmitters and is involved in synaptogenesis, synaptic plasticity, memory function, and neuroendocrine secretion [129]. NO might also play a protective role in AD. Bis(7)-tacrine is able to reduce glutamate-induced NO generation [130] and Li et al. [131] showed that the neuroprotection of bis(7)-tacrine can be mediated through the inhibition of neuronal nitric oxide synthase (nNOS) and through the moderate blockade of NMDA-receptors, as this receptor plays a role in inhibiting endogenous NOS. Kinetic studies have confirmed that bis(7)-tacrine selectively inhibits the NOS in a competitive manner. NO-donor-tacrine hybrids have been synthesized during research into the development of safer anti-Alzheimer drugs [132], and these hybrid molecules inhibited cholinesterases and some showed much less hepatotoxicity than tacrine in addition to possessing vasorelaxation effects.

\subsection{Hybrid Molecules of Tacrine and Inhibition of Aß Amyloid Aggregation}

The death of neuronal cells is associated with the development of of amyloid aggregation (Section 3 ). Under normal conditions, $A \beta$ peptides are degraded by the lysosomes after autophagosome/endosome fusion. It has recently been demonstrated that $A \beta$ peptides are toxic for mitochondria and that $A \beta$ 
peptides are transported into mitochondria via the mitochondrial translocase of the outer membrane machinery. Genes related to mitochondrial energy metabolism and apoptosis are upregulated before and during the appearance of $\mathrm{A} \beta$ plaques. It has also been suggested that autophagic insufficiency results in an accumulation of dysfunctional mitochondria and aberrant protein aggregates [133-138]. In addition to its catalytic function, $\mathrm{AChE}$ can also bind to $\mathrm{A} \beta$ peptide and act as a promoter of amyloid $\mathrm{A} \beta$ formation. This action is associated with PAS of AChE and such AChEI which bind to PAS could retard this aggregation.

Apoptosis is a major form of neuronal cell death and the link between autophagy and diseases associated with protein aggregation has been confirmed, although the trigger of this cellular misbalance is not yet known. Autophagy is an adaptation process, and if this process is defective than the suitable conditions for intracellular $A \beta$ accumulation and cell death are created [139-144]. It is known that autophagic process can proceed to apoptosis. Apoptosis and autophagy share some similar hallmarks, e.g., calpains are activated during these processes but caspases are activated only during apoptosis. The action of an AChE on the autophagy of neuronal cells has not been clarified and multifunctional AChEIs could help to explain the action of AChE on cell death. Escobar-Khondiker et al. [144] showed that mitochondrial disturbances lead to a decrease in ATP levels that could induce A $\beta$ misfolding. The interaction between $A \beta$ peptide and beclin1 is not clear. Externally added $A \beta$ peptides decreased mitochondrial function and also induced a strong autophagic response. Furthermore, the inhibition of autophagosome formation in $A \beta$ treated cells significantly enhanced its toxicity.

The neuroprotective effects of tacrine hybrids could be associated with the inhibition of AChEinduced $A \beta$ aggregation and inhibition of $\beta$-secretase. Two isomeric series of dual binding site acetylcholinesterase inhibitors have recently been designed and synthesized by Camps et al [64]. These hybrids, consisting of a unit of 6-chlorotacrine and pyrano[3,2-c]quinoline, possessed the potent and selective human AChE inhibitory activity and exhibited a significant in vitro inhibitory activity toward the AChE-induced and self-induced $\mathrm{A} \beta$ aggregation and toward $\beta$-secretase, in addition to the ability to enter the central nervous system.

\subsection{Hybrid Molecules of Tacrine and Changes of Calcium Transport}

Calcium is a second messenger and intracellular $\mathrm{Ca}^{2+}$ plays an important role in the modulation of cellular death. Overload of $\mathrm{Ca}^{2+}$ has even been suggested to be the final common pathway of all types of cell death [145-147]. Critical role for calcium dysregulation in the pathogenesis of AD has been discussed [148-151]. Zhu et al. [150] showed that cytosolic $\mathrm{Ca}^{2+}$ plays a key role in AChE regulation during apoptosis. The concentration of cytosolic $\mathrm{Ca}^{2+}$ has an important role in the modulation of apoptosis, and AChE expression during apoptosis is related to $\mathrm{Ca}^{2+}$ mobilization. It has been suggested that calcium dysregulation can implicated as a major contributor to neuronal cell death in AD. Green and LaFerla [147] have confirmed that calcium homeostasis was perturbed in dendritic spines adjacent to amyloid plaques. The neuroprotectivity of AChE inhibitors could be associated mainly with their action on the intracellular accumulation of $\mathrm{Ca}^{2+}$. Their direct effects on voltage-dependent $\mathrm{Ca}^{2+}$ channels, $n$ AChRs (nicotinic acetylcholine receptors) or NMDA ( $N$-methyl-D-aspartate) receptors have been studied very intensively. It has been confirmed that tacrine is able to inhibit voltage-dependent $\mathrm{Ca}^{2+}$ channels in dorsal root ganglion cells [152] and also to interact with nicotinic receptors [153-155]. 
Several series' of tacrine derivatives have been synthetized and their biological activity as inhibitors of AChE as well as modulators of voltage-dependent $\mathrm{Ca}^{2+}$ channels and nicotinic receptors has been evaluated [153-155]. Some of the tacrine hybrid molecules exhibited neuroprotectant effects and inhibited AChE. Recently Marco-Contelles et al. [156] prepared tetracyclic tacrine, tacrine-dihydropyridine hybrids to achieve a blockade of $\mathrm{Ca}^{2+}$ entry through neuronal voltage-dependent $\mathrm{Ca}^{2+}$ channels. They showed that tacripyrines were selective and potent AChE inhibitors in the nanomolar range and that these compounds were able to inhibit the proaggregating action of $\mathrm{AChE}$ on the A $\beta$. Tacripyrines showed a moderate $\mathrm{Ca}^{2+}$ channel blocking effect.

A significant loss of $n \mathrm{AChR}$ and certain types of muscarinic ACh receptors in brains affected by AD has been confirmed $[157,158]$. Tadaka-Takori et al. [159] studied the mechanism of neuroprotectivity of acetylcholinesterase inhibitors, including tacrine which protect neurons from glutamate-induced neurotoxicity in the primary culture of rat cortical neurons. They concluded that AChEI are able to induce up-regulation of nicotinic receptor expression levels.

The NMDA receptor is a key player implicated in the regulation of learning and memory and it was supposed that that one of the targets of AChE inhibitors involved in cognitive process is the NMDARmediated synaptic response in prefrontal cortex neurons [160]. Bis(7)-tacrine is a noncompetitive antagonist of NMDA receptors that can prevent glutamate-induced damage to hippocampal neurons [161]. Fang et al. [162] confirmed that bis(7)-tacrine prevented glutamate-induced cell death. They confirmed the anti-apoptosis effects of bis(7)-tacrine and their results showed that bis(7)-tacrine had neuroprotective effects against glutamate-induced RGCs (retinal ganglion cells) damage in vitro and in vivo. Luo et al. [163] studied analogues of bis(7)-tacrine and demonstrated that bis(propyl)-tacrine inhibited AChE and acted as a $\gamma$-aminobutyric acid subtype A receptor antagonist, and an antagonist of NMDA receptors. In cultured rat hippocampal neurons, bis(propyl)-tacrine voltage-dependently, selectively, and moderately inhibited NMDA-activated currents. The inhibitory effects of this AChEI increased with the rise in NMDA and glycine concentrations. Under glutamate-mediated pathological conditions, bis(propyl)-tacrine, in contrast to bis(7)-tacrine, prevented excitotoxicity with increasing effectiveness against escalating levels of glutamate and protected against middle cerebral artery occlusion-induced brain damage much more effectively than memantine.

$\mathrm{AD}$ is characterized by the depletion of $n \mathrm{AChR}$. Many studies have demonstrated that the persistent stimulation of certain subtypes of $n$ AChRs, such as $\alpha 4$ and $\alpha 7$, protect against neurotoxicity induced by glutamate and $\mathrm{A} \beta$. The AChEIs, including tacrine, are able to protect against neuronal death induced by moderate glutamate treatment, and although it is known that $n \mathrm{AChR}$ subtypes are involved in tacrine-induced neuroprotection, the intracellular mechanisms involved are not clear [126,158]. Tacrine or its analogues are able to inhibit the apoptotic process, although they act indirectly, through their effect on $\mathrm{Ca}^{2+}$ homeostase. Recently, the hypothesis that AChE play a role in apoptosis has been made on the basis of information that this enzyme was first detected in the cytoplasm in the early stages of apoptosis and at later stages in the nucleus [164,165]. Park et al. [166,167] proposed that AChE even can assemble apoptosomes with apoptotic protease-activating factor-1 (Apaf-1) and cytochrome c, and activate caspase 9. If apoptosis was induced, the silencing of the AChE gene blocked the interaction between cytochrome c and Apaf-1. It was shown that AChE interacted with caveolin-1 in cells undergoing apoptosis. This association of AChE with caveolin-1 is required for the interaction between AChE and cytochrome c. The interaction between AChE and caveolin-1 could be 
indispensable for apoptosome formation. The interaction of AChE with other apoptotic molecules during apoptosis is not completely clear. Recently, Ye et al. [168] studied the relationship between $\mathrm{AChE}$ and classical apoptotic molecules during apoptosis, and confirmed that AChE-S plays a pro-apoptotic role and regulates p53 and Bcl-2 family proteins expression during ischemia/reperfusion induced apoptosis. Toiber et al. [169] showed that overexpression of an $N$-terminally extended synaptic acetylcholinesterase variant, $N$-AChE-S, induced cell death. These newly discover functions of AChE, its interactions with apoptotic proteins, suggest the potential value of AChEIs in AD therapy.

\section{Conclusions}

In this review, recent findings concerning new tacrine hybrids which act as cholinesterase (AChE and $\mathrm{BChE}$ ), and $\beta$-amyloid aggregation inhibitors are summarized. Our attention is focused on dividing these derivatives in following groups: monomeric, homodimeric and heterodimeric congenes, which have the ability to simultaneously bind to both the active and peripheral binding sites of AChE. It is of interest to note the impact of the length and nature of the chain connecting the two skeletons (anchor groups) in relation to the increase in their inhibitory effect. The data suggests that the optimal length of the tether is from 6 to 11 units (methylenes, amides and other). The desolvatation of free energy is also important in this context, suggesting the importance of ligand hydrophobicity for effective interaction with the peripheral side. The most effective inhibitors were found to be the hybrids of tacrine moiety with indanone, 8-hydroxychinoline, indole 3-methoxy-substituted benzene and others. Furthermore, numerous tacrine hybrids have been developed with the aim of improving and enlarging the biological profile beyond its ability to act as ChEIs. Amyloid aggregates are toxic for neurons and influence the direct or indirect origins of the pathological conditions associated with the disease. The precise mechanisms of toxicity have not been fully elucidated; however, there is evidence that the reduction of amyloid deposits leads to the alleviation of the disease's symptoms. Anti-amyloid activity has been observed for several tacrine-based compounds. It was found that both the structure of tacrine derivate and the formation of dimeric or multimeric tacrine conjugates affect the extent of the inhibiting properties of these tacrine derivatives. The development of amyloid aggregation inhibitors would also be able to disaggregate filaments and provide an alternative to existing pharmaceutical strategies. In principle, the inhibitory effect of compounds could take place on different levels, for example, interference with the association of dimmers or oligomers and elongation of filaments. This can be achieved by tight binding of the compounds to the protein monomer and oligomer.

One of the hallmarks of $\mathrm{AD}$ is the loss of cholinergic neurons and it is well known that $\mathrm{A} \beta$ peptides and higher level of AChE (confirmed in cholinergic neurons in brains affected by AD) are able to induce cell death. The elucidation of the mechanism of neuronal death in brains affected by AD and new functions of AChE are of importance for the development of new drug designs. New types of multifunctional AChEI, with antioxidant potential, an ability to reduce of amyloid aggregation and to interrupt the aberrant influx of $\mathrm{Ca}^{2+}$ could be a promising treatment for $\mathrm{AD}$, which explains why hybrid molecules of tacrine are under development as promising drugs. 


\section{Acknowledgements}

The work was supported by the Grant Agency VEGA-grants 1/0179/11, 2/0097/10, 2/0079/10, CEX SAS Nanofluid.

\section{References}

1. Shaw, H.; Bentley, G. Some aspect of the pharmacology of morphine with special reference to its antagonism by 5 -aminoacridine and other chemically related compounds. Med. J. Auts. 1949, 2 , 868-875.

2. Albin, S.M.; Bunegin, B.; Massopust, L.C.; Jannetta, P. Ketamine-induced postanesthesic delirium attenuated by tetrahydroaminoacridine. Exp. Neurol. 1974, 44, 126-129.

3. Gordh, T.; Walin, A. Potential of the neuromuscular effect of succinylcholine by tetrahydroaminoacridine. Acta Anaesth. Scand. 1961, 5, 55-61.

4. Heilbronn, E. Inhibition of cholinesterase by tetrahydroaminoacric. Acta. Chem. Scand. 1961, 15, 1386-1390.

5. Giacobini, E. Cholinesterase inhibitors for Alzheimer's therapy: from tacrine to future applications. Neurochem. Int. 1998, 32, 413-419.

6. Drukarch, B.; Leysen, J.E.; Stoof, J.C. Further analysis of the neuropharmacological profile of 9-amino-1,2,3,4-tetrahydroacridine (THA), an alleged drug in the treatment of Alzheimer's disease. Life Sci. 1988, 42, 1011-1017.

7. Chuh, A.A.T. A review of the drug treatment of Alzheimer's disease. JHKC Psych. 1993, 3, 51-58.

8. Beecker, R.; Giacobini, E.; Elbe, R.; Malhany, M.; Sherman, K. Potential pharmacotherapy of Alzheimer disease. A comparison of various forms of physostigmine administration. Acta Neurol. Scand. Suppl. 1988, 116, 13-32.

9. Summers, W.K.; Majowski, L.V.; March, G.M.; Tachiki, K.; Kling, A. Oral tetrahydroacridine in long-term treatment of senile dementia. N. Engl. J. Med. 1986, 315, 1241-1245.

10. Marx, J.L. Alzheimer's drugs trial put on hold. Science 1987, 238, 1041-1042.

11. Crimson, M.L. Tacrine: First drug approved for Alzheimer's disease. Ann. Pharmacother. 1994, 28, 744-751.

12. Wagstaff, A.J.; McTavish, D. Tacrine. A review of its pharmacodynamic and pharmacokinetic properties, and therapeutic efficacy in Alzheimer's disease. Drugs Aging 1994, 4, 510-540.

13. Delfino, E.T.; Ribeiro, T.S.; Figueroa-Villar, J.D. Organophosphorus compounds as chemical warfare agents: a review. J. Braz. Chem. Soc. 2009, 20, 407-428.

14. Belleau, B.; DiTullio, V; Tsai, Y.H. Kinetic effects of leptocurares and pachycurares on the methanesulfonylation of acetylcholinesterase. A correlation with pharmacodynamic properties. Mol. Pharmacol. 1970, 6, 217-224.

15. Colletier, J.-P.; Fournier D.; Greenblatt, H.M.; Stojan, J.; Sussman, J. L.; Zaccai, G.; Weik, M. Strucrural insight into substrate traffic and inhibition in acetylcholinesterase. EMBO J. 2006, 25, 2746-2756. 
16. Sussman, J.L.; Harel, M.; Frolow, F.; Oefner.C.; Goldman, A.; Toker, L.; Silman, I. Atomic structure of acetylcholinesterase from Torpedo californica: a protopic acetylcholine-binding protein. Science 1991, 253, 827-879.

17. Nicolet, Y.; Lockridge, O.; Masson, P.; Fontecilla-Camps, J.C.; Nachon, F. Crystal structure of human butyrylcholinesterase and of its ccomplexes with substrate and products. J. Biol. Chem. 2003, 278, 41141-41147.

18. Szegletes, T.; Mallender W.D.; Rosenberry, T.L. Nonequilibrium analysis alters the mechanistic interpretation of inhibition of acetylcholinesterase by peripheral site ligands. Biochemistry 1998, 37, 4206-4216.

19. Shen, Z-X. Rationale for diagnosing deficiency of ChEs and for applying exogenous HuChEs to the treatment of diseases. Med. Hypothesis 2008, 70, 43-51.

20. Lane, R.M.; Potkin, S.G.; Enz, A. Targeting acetylcholinesterase and butyrylcholinesterase in dementia. Int. J. Neuropsychopharmacol. 2006, 9, 101-124.

21. Arendt, T.; Bruckner, M.K.; Lange. M.; Bigl, V. Changes in acetylcholinesterase and butyrylcholinesterase in Alzheimer's disease resemble embryonic development - a study of molecular forms. Neurochem. Int. 1992, 21, 381-396.

22. Ballard, C.G.; Greig, N.H.; Guillozet-Bongaarts, A.L.; Enz, A.; Darvesh, S. Cholinesterases: roles in the brain during health and disease. Curr. Alzheimer Res. 2005, 2, 307-318.

23. Greig, N.H.; Utsuki, T.; Ingram, D.K.; Wang, Y.; Pepeu, G.; Scali, C.; Yu, Q.S.; Mamczarz, J.; Holloway, H.W.; Giordano, T.; Chen, D.; Furukawa, K.; Sambamurti, K.; Brossi, A.; Lahiri, D.K. Selective butyrylcholinesterase inhibition elevates brain acetylcholine, augments learning and lowers Alzheimer beta-amyloid peptide in rodent. Proc. Natl. Acad. Sci. USA 2005, 102, 17213-17218.

24. Ballard, C.G.; Perry, E.K. In Butyrylcholinesterase its Function and Inhibitors; Giacobini, E., Ed.; Martin Dunitz, London, UK, 2003, p. 123.

25. Pepeu, G.; Giovannini, M.G.; Cholinesterase inhibitors and beyond. Curr. Alzheimer Res. 2009, 6, 86-96.

26. Fifer, E.K. Drug affecting cholinergic neurotransmission. In Foye's Principles of Medicinal Chemistry, 6th ed.; Lemke, T., Williams, D.A., Roche, V., Zito, S.W. Eds.; Lippincott, Williams and Wilkins, Baltimore, USA, 2008, pp. 361-392.

27. Reichman, W.E. Current pharmacologic options for patients with Alzheimer's disease. Ann. Gen. Hosp. Psychiatr. 2003, 2, 1-14.

28. Qizilbash, N.; Birks, J.; López-Arrieta, J., Lewington, S.; Szeto, S. Tacrine for Alzheimer's disease. Cochrane Database Syst. Rev. 2000, 2, CD000202.

29. Albert, A.; Gledhill, W.J. Improved synthesis of aminoacridines. J. Soc. Chem. Ind. 1945, 64, 169.

30. Kaul, P.N. Enzyme inhibiting action of tetrahydroaminoacridine and its structural fragments. J. Pharm. Pharmacol. 1962, 14, 243-248.

31. Clarke, P.B.; Reuben, M.; el-Bizri, H. Blockade of nicotinic responses by physostigmine, tacrine and other cholinesterase inhibitors in rat striatum. Br. J. Pharmacol. 1994, 111, 695-702.

32. Hallivel, J.V.; Grove, E.A. 9-Amino-1,2,3,4-tetrahydroacridine (THA) blocks agonist-induced potassium conductance in rat hippocampal neurones. Eur. J. Pharmacol. 1989, 163, 369-372. 
33. Perry, E.K.; Smith, C.J.; Court, J.A.; Bonham, J.R.; Rodway, M.; Atack, J.R. Interaction of 9-amino-1,2,3,4-tetrahydroaminoacridine (THA) with human cortical nicotinic and muscarinic receptor binding in vitro. Neurosci. Lett. 1988, 91, 211-216.

34. Patocka, J.; Jun, D.; Kuca, K. Possible role of hydroxylated metabolites of tacrine in drug toxicity and therapy of Alzheimer's disease. Cur. Drug Metab. 2008, 9, 332-335.

35. Proctor, G.R.; Harvey, A.L. Synthesis of tacrine analogues and their structure-activity relationships. Curr. Med. Chem. 2000, 7, 295-302.

36. Pang, Y.P., Quiram, P.; Jelacic, T.; Hong, F.; Brimijoin, S. Highly potent, selective, and low cost bis-tetrahydroaminacrine inhibitors of acetylcholinesterase. Steps toward novel drugs for treating Alzheimer's disease. J. Biol. Chem. 1996, 271, 23646-23649.

37. Tumiatti, V.; Minarini, A.; Bolognesi, M.L.; Milelli, A.; Rosini, M.; Melchiorre, C. Tacrine derivatives and Alzheimer's disease. Curr. Med. Chem. 2010, 17, 1825-1838.

38. Marco-Contelles, J.; León, R.; de los Ríos, C.; García, A.G.; López, M.G.; Villarroya, M. New multipotent tetracyclic tacrines with neuroprotective activity. Bioorg. Med. Chem. 2006, 14, 8176-8185.

39. Butini, S.; Guarino, E.; Campiani, G.; Brindisi, M.; Coccone, S. S.; Fiorini, E.; Novellino, E.; Belinskaya, T.; Saxena, A.; Gemma, S. Tacrine based human cholinesterase inhibitors: Synthesis of peptidic-tethered derivatives and their effect on potency and selectivity. Bioorg. Med. Chem. Lett. 2008, 18, 5213-5216.

40. León, R.; de los Ríos, C.; Marco-Contellee, J.; Huertas, O.; Barril, X.; Luque, F.J.; López, M.G.; García, A.G.; Villarroya, M. New tacrine-dihydropyridine hybrids that inhibit acetylcholinesterase, calcium entry, and exhibit neuroprotection properties. Bioorg. Med. Chem. 2008, 16, 7759-7769.

41. Birks, J. Cholinesterase inhibitors for Alzheimer's disease. Cochrane Database Syst. Rev. 2006, 1 , CD005593.

42. Haviv, H.; Wong, D.M.; Silman, I.; Sussman, J.L. Bivalent ligands derived from Huperzine A as acetylcholinesterase inhibitors. Curr. Top. Med. Chem. 2007, 7, 375-387.

43. Wang, R.; Yan, H.; Tang, X.C. Progress in studies of Huperzine A, a natural cholinesterase inhibitor from Chinese herbal medicine. Acta Pharmacol. Sin. 2006, 27, 1-26.

44. Li, J.; Wu, H.M.; Zhou, R.L.; Liu, G.J.; Dong, B.R. Huperzine A for Alzheimer's disease. Cochrane Database Syst. Rev. 2008, CD005592.

45. Wang, R.; Yan, H.; Tang, X. Progress in studies of Huperzine A, a natural cholinesterase inhibitor from Chinese herbal medicine. Acta Pharmacol. Sin. 2006, 27, 1-26.

46. Shen, Y.; Zhang, J.; Sheng, R.; Dong, X.; He, Q.; Yang, B.; Hu, Y. Synthesis and biological evaluation of novel flavonoid derivatives as dual binding acetylcholinesterase inhibitors. J. Enzyme Inhib. Med. Chem. 2009, 24, 372-380.

47. Giacobini E. From molecular structure to Alzheimer therapy. Jpn. J. Pharmacol. 1997, 74, 225-241.

48. Musiał, A.; Bajda, M.; Malawska, B. Recent developments in cholinesterases inhibitors for Alzheimer's disease treatment. Curr. Med. Chem. 2007, 14, 2654-2679.

49. Martinez, A.; Castro, A. Novel cholinesterase inhibitors as future effective drugs for the treatment of Alzheimer's disease. Expert. Opin. Investig. Drugs 2006, 15, 1-12. 
50. Recanatini, M.; Cavalli, A.; Belluti, F.; Piazzi, L.; Rampa, A.; Bisi, A.; Gobbi, S.; Valenti, P.; Andrisano, V.; Bartolini, M.; Cavrini, V. SAR of 9-amino-1,2,3,4-tetrahydroacridine-based acetylcholinesterase inhibitors: Synthesis, enzyme inhibitory activity, QSAR, and structure-based CoMFA of tacrine analogues. J. Med. Chem. 2000, 43, 2007-2018.

51. Pisoni, D, dos S.; Sobieski da Costa, J.; Gamba, D.; Petzhold, C.L.; Borges, A, C de A.; Ceschi, M.A.; Lunardi, P. Synthesis and AChE inhibitory activity of new chiral tetrahydroacridine analoques from terpenic cyclanones. Eur. J. Med. Chem. 2010, 45, 526-535.

52. Hamul'aková, S.; Kristian, P.; Jun, D.; Kuča, K.; Imrich, J.; Danihel, I.; Bőhm, S.; Klika, K.D. Synthesis, structure, and cholinergic effect of novel neuroprotective compounds bearing the tacrine pharmacophore. Heterocycles 2008, 76, 1219-1235.

53. Patočka, J. Anticholinesterase activity of 9-amino-7-methoxy-1,2,3,4-tetrahydroacridine and some derivatives and analoques. Sbornik ved. prac. VLVDU Hradec Kralove 1986, 102, 123-140.

54. Musilek, K.; Holas, O.; Kuca, K.; Jun, D.; Dohnal, V.; Opletalova, V.; Dolezal, M. Novel series of bispyridinium compounds bearing a (Z)-but-2-ene linker-Synthesis and evaluation of their reactivation activity against tabun and paraoxon-inhibited acetylcholinesterase. Bioorg. Med. Chem. 2007, 17, 3172-3176.

55. Korabecny, J.; Musilek, K.; Holas, O.; Binder, J.; Zemek, F.; Marek, J.; Pohanka, M.; Opletalova, V.; Dohnal, V.; Kuca, K. Synthesis and in vitro evaluation of $N$-alkyl-7-methoxytacrine hydrochlorides as potential cholinesterase inhibitors in Alzheimer disease. Bioorg. Med. Chem. Lett. 2010, 20, 6093-6095.

56. Li, W.; Mak, M.; Jiang, H.; Wang, Q.; Pang, Y.; Chen, K.; Han, Y. Novel anti-Alzheimer's dimer Bis(7)-cognitin: Cellular and molecular mechanisms of neuroprotection through multiple targets. Neurotherapeutics 2009, 6, 187-201.

57. Gorun, V.; Proinov, I.; Baltescu, V.; Balaban, G.; Barzu, O. Modified Ellman procedure for assay of cholinesterases in crude enzymatic preparation. Anal. Biochem. 1978, 86, 324-326.

58. Wang, H.; Carlier, P.; Ho, W.L.; Wu, D,Ch.; Lee, Nelson T.K.; Li, C.P.L.; Pang, Y.P.; Han, Y. Effects of bis(7)-tacrine, a novel anti-Alzheimer's agent, on rat brain AChE. Neuropharmacology 1999, 10, 789-793.

59. Carlier, P.R.; Chow, E.S.-H.; Han, Y.; Liu, J.; Yazal, J.E.; Pang, Y.-P. Heterodimeric tacrinebased acetylcholinesterase inhibitors: Investigating ligand-peripheral site interactions. J. Med. Chem. 1999, 42, 4225-4231.

60. Carlier, P.R.; Han, Y.F.; Chow, E.S.-H.; Li, C.P.-L.; Wang, H.; Lieu, T.X.; Wong, H.S.; Pang, Y.-P. Evaluation of short-tether bis-THA AChE inhibitors. A further test of the dual binding site hypothesis. Bioorg. Med. Chem. 1999, 7, 351-357.

61. Savini, L.; Campiani, G.; Gaeta, A.; Pellerano, C.; Fattorusso, C.; Chiasserini, L.; Fedorko, J.M.; Saxena, A. Novel and potent tacrine-related hetero- and homobivalent ligands for acetylcholinesterase and butyrylcholinesterase. Bioorg. Med. Chem. Lett. 2001, 11, 1779-1782.

62. Hu, M.-K.; Wu, L.J.; Hsiao, G.; Yen, M.-H. Homodimeric tacrine congeners as acetylcholinesterase inhibitors. J. Med. Chem. 2002, 45, 2277-2282. 
63. Badia, A.; Baños, J.E.; Camps, P.; Contreras, J.; Görbig, D.M.; Muñoz-Torrero, D.; Simon, M.; Vivas, N.M. Synthesis and evaluation of tacrine-huperzine A hybrids as acetylcholinestrase inhibitors of potential interest for the treatment of Alzheimer's disease. Bioorg. Med. Chem. 1998, 6, 427-440.

64. Camps, P.; Formosa, X.; Galdeano, C.; Gómez, T.; Munoz-Torrero, D.; Ramírez, L.; Viayna, E.; Gómez, E.; Isambert, N.; Lavilla, R.; Badia, A.; Clos, M.V.; Bartoliny, M.; Mancini, F.; Andrisano, V.; Bidon-Chanal, A.; Huertas, Ó.; Dafni, T.; Luque, F.J. Tacrine-based dual binding site acetylcholinesterase inhibitors as potential disease-modifying anti-Alzheimer drug candidates. Chem. Biol. Interact. 2010, 187, 411-415.

65. Camps, P.; Formosa, X.; Galdeano, C.; Muñoz-Torrero, D.; Ramírez, L.; Gómez, E.; Isambert, N.; Lavilla, R; Badia, A; Clos, M.V.; Bartolini, M; Mancini, F; Andrisano, V.; Arce, M.P.; Rodríguez-Franco, M.I.; Huertas, O.; Dafni, T.; Luque, F.J. Pyrano[3,2-c]quinoline-6chlorotacrine hybrids as a novel family of acetylcholinesterase- and beta-amyloid-directed antiAlzheimer compounds. J. Med. Chem. 2009, 52, 5365-5379.

66. Shao, D.; Zou, Ch.; Luo, Ch.;Tang, X.; Li, Y. Synthesis and evaluation of tacrine-E2020 hybrids as acetylcholinesterase for the treatment of Alzheimer's disease. Bioorg. Med. Chem. Lett. 2004, 14, 4639-4642.

67. Camps, P.; Formosa, X.; Galdeano, C.; Gómez, T.; Muñoz-Torrero, D.; Scarpellini, M.; Viayna, E.; Badia, A; Clos, V.; Camins, A.; Pallás, A.; Bartolini., M; Mancini., F; Andrisano, V.; Estelrich, J.; Lizondo, M.; Bidon-Chanal, A.; Luque, F.J. Novel donepezil-based inhibitors of acetyl- and butyrylcholinesterase and acetylcholinesterase-induced $\beta$-amyloid aggregation. J. Med. Chem. 2008, 51, 3588-3598.

68. Hamul'aková, S.; Kuča, K.; Janovec, L.; Kožurková, M.; Kristian, P.; Danihel, I.; Imrich, J. Synthesis, Neuroprotective and structural studies of novel bivalent tacrine/acridine congeners with high efficacy and selectivity against acetyl/butyryl cholinesterase. Adv. Org. Chem. 2010, 71.

69. Hamulakova, S.; Imrich, J.; Janovec, L.; Kristian, P.; Danihel, I.; Holas, O.; Pohanka, M.; Bohm, S.; Kozurkova, M.; Kuca, K. Homo- and hetero tacrine/acridine congeners with sub-nanomolar activity and selectivity against acetylcholinesterase/butyrylcholinesterase: Synthesis and docking studies. J. Med. Chem. 2011, submitted.

70. Kožurková, M,; Sabolová, D.; Hamul’aková, S.; Janočková, J.; Plšíková, J.; Kristian, P.; Imrich, J.; Janovec, L.; Holas, O.; Pohanka, M.; Kuča, K. Studies of novel bivalent tacrine derivatives targeting acetylcholinesterases In: XXII. Biochem.Congr. 2010, 203.

71. Alonso, D.; Dorronsoro I.; Rubio, L.; Munoz, P.;García-Palomero, E.; Del Monte, M.; BidonChanal, A.; Orozco, M.; Luque, F. J.; Castro, A.; Medina, M.; Martínez, A. Donepezil-tacrine hybrid related derivatives as new dual binding site inhibitors of AChE. Bioorg. Med. Chem. 2005, 13, 6588-6597.

72. Muňoz-Ruiz, P; Rubio, L.; García-Palomero, E.; Dorronsoro, I.; del Monte-Millán, M.; Venezuela, R.; Usán, P.; de Austria, C.; Bartoliny, M.; Andrisano, V.; Bidon-Chanal, A.; Orozco, M.; Luque, F.J.; Medina, M.; Martínez, A. Design, synthesis, and biological evaluation of dual binding site acetylcholinesterase inhibitors: New disease-modifying agents for Alzheimer's disease. J. Med. Chem. 2005, 48, 7223-7233. 
73. Elsinghorst, P.W.; Gonzáles Tanarro, C.M.; Gütschow, M. Novel heterobivalent tacrine derivatives as cholinesterase iInhibitors with notable selectivity toward butyrylcholinesterase. J. Med. Chem. 2006, 49, 7540-7544.

74. Fernández-Bachiller, M.I.; Pérez, C.; González-Muňoz, G.C.; Conde, S.; López, M.G.; Villaroya, M.;García, A.G.; Rodríquez-Franco, M.I. Novel tacrine-8-hydroxyquinoline hybrids as multifunctional agents for the treatment of Alzheimer's disease, with neuroprotective, cholinergic, antioxidant, and copper-complexing properties. J. Med. Chem. 2010, 53, 4927-4937.

75. Bolognesi, M.L; Cavalli, L; Valgimigli, L.; Bartolini, M.; Rosini, M.; Andrisano, V.; Recanatini, M.; Melchiorre, C. Multi-target-directed drug design strategy: From a dual binding site acetylcholinesterase inhibitor to a trifunctional compound against Alzheimer's disease. J. Med. Chem. 2007, 50, 6446-6449.

76. Fang, L.; Appenroth, D.; Decker, M.; Kiehntopf, M.; Roegler, C.; Deufel, T.; Fleck, Ch.; Peng, S.; Zhang, Y.; Lehmann, J. Synthesis and biological evaluation of NO-donor-tacrine hybrids as hepatoprotective anti-Alzheimer drug candidates. J. Med. Chem. 2008, 51, 713-716.

77. Fang, L.; Kraus, B.; Lehmann, J.; Heilmann, J.; Zhang, Y.; Decker, M. Design and synthesis of tacrine-ferulic acid hybrids as multi-potent anti-Alzheimer drug candidates. Bioorg. Med. Chem. Lett. 2008, 18, 2905-2909.

78. Lange, J.H.M.; Coolen, H.K.A.C.; van der Neut, M.A.W.; Borst, A.J.M.; Stork, B.;Verveer, P.C.; Kruse, C.G. Design, synthesis, biological properties, and molecular modeling investigations of novel tacrine derivatives with a combination of acetylcholinesterase inhibition and cannabinoid $\mathrm{CB}_{1}$ receptor antagonism. J. Med. Chem. 2010, 53, 1338-1346.

79. Marco-Contelles, J.; León, R.; de los Ríos, C.; Guglietta, A.; Terencio, J.; López, M. G.; García, A.G.; Villarroya, M. Novel multipotent tacrine-dihydropyridine hybrids with improved acetylcholinesterase inhibitory and neuroprotective activities as potential drugs for the treatment of Alzheimer's disease. J. Med. Chem. 2006, 49, 7607-7610.

80. Sipe, J.D. Amyloid Proteins; Wiley-VCH Verlag GmbH and Co. KgA: Weinheim, Germany, 2005.

81. Jarret, J.T.; Berger, E.P; Lansbury, Jr. The carboxy terminus of the beta amyloid protein is critical for the seeding of amyloid formation: implications for the pathogenesis of Alzheimer's disease. Biochemistry 1993, 32, 4693-4697.

82. Baglioni, S.; Casamenti, F.; Bucciantini, M; Luheshi, L.; Taddei, N.; Chiti, F.; Dobson, C.M.; Stefani, M. Prefibrillar amyloid aggregates could be generic toxins in higher organisms. J. Neurosci. 2006, 26, 8160-8167.

83. Ferreira, S.T.; Vieira, M.N.; DeFelice, F.G. Soluble protein oligomers as emerging toxins in Alzheimer's and other amyloid diseases. IUBMB Life 2007, 59, 332-345.

84. Walsh, D.M.; Selkoe, D.J. Oligomers on the brain: the emerging role of soluble protein aggregates in neurodegeneration. Protein Pept. Lett. 2004, 11, 213-228.

85. De Felice, F.G.; Velasco, P.T.; Lambert, M.P.; Viola, K.; Fernandez, S.J.; Ferreira, S.T.; Klein, W.L. Abeta oligomers induce neuronal oxidative stress through an $N$-methyl-D-aspartate receptordependent mechanism that is blocked by the Alzheimer drug memantine. J. Biol. Chem. 2007, 282, 11590-11601. 
86. Gouras, G.K.; Almeida, C.G.; Takahashi, R.H. Intraneuronal Abeta accumulation and origin of plaques in Alyheimer's disease. Neurobiol. Aging 2005, 26, 1235-1244.

87. Moreira, P.I; Honda, K.; Liu, Q.;Santos, M.S.; Oliviera, C.R.; Aliev, G.; Nunomura, A.; Zhu, X.; Smith, M.A.; Perry, G. Oxidative stress: the old enemy in Alzheimer's disease pathophysilogy. Curr. Alzheimer Res. 2005, 2, 403-408.

88. Roberson, E.D.; Scearce-Levie, K.; Palop, J.J.; Yan, F.; Cheng, I.H.; Wu, T.; Gerstein, H.; Yu, G.Q. Mucke, L. Reducing endogenous tau ameliorates amyloid beta-induced deficits in an Alzheimer's disease mouse model. Science 2007, 316, 750-754.

89. Khlistunova, I.; Biernat, J.; Wang, Y.P.; Pickhardt, M.; von Bergen, M.; Gazova, Z.; Mandelkow, E.M.; Mandelkow, E. Inducible expression of Tau repeat domain in cell models of tauopathy: aggregation is toxic to cells but can be reversed by inhibitor drugs. J. Biol. Chem. 2006, 281, 1205-1214.

90. DeFelice, F.G.; Houzel, J.C.; Garcia-Abreu, J.; Louzada, P.R.F., Afonso, R.C.; Meirelles, N.L.; Lent, R.; Neto, M.V.; Ferreira, S.T. Inhibition of Alzheimer's disease beta/amyloid aggregation, neurotoxicity, and in vivo deposition by nitrophenols: implications for Alzheimer's theraphy. FASEB J. 2001, 15, 1297-1299.

91. Raghu, P.; Reddy, G.B.; Sivakumar, B. Inhibition of transthyretin amyloid fibril formation by 2,4dinitrophenol through tetramer stabilization. Arch. Biochem. Biophys. 2002, 400, 43-47.

92. Caughey, W.S.; Raymond, L.D.; Horiuchi, M.; Caughey, B. Inhibition of protease-resistant prion protein formation by porphyrins and phthalocyanines. Proc. Natl. Acad. Sci. USA 1998, 95, 12117-12122.

93. Kim, H.; Park, B.S.; Lee, K.G.; Choi, C.Y.; Jang, S.S.; Kim, Y.H.; Lee, S.E. Effects of naturally occurring compounds on fibril formation and oxidative stress of beta-amyloid. J. Agric. Food Chem. 2005, 53, 8537-8541.

94. Dolphin, G.T.; Renaudet, O.; Quberai, M.; Dumy, P.; Garcia, J.; Reymond, J.L. Phenolic oxime oligomers inhibit Alzheimer's amyloid fibril formation and disaggregate fibrils in vitro. ChemBioChem 2009, 10, 1325-1329.

95. Wischik, C.M.; Edwards, P.C.; Lai, R.Y.K.; Roth, M.; Harrington, C.R. Selective inhibition of Alzheimer disease-like tau aggregation by phenothiazines. Proc. Natl. Acad. Sci. USA 1996, 93, 11213-11218.

96. Brunden, K.R.; Ballatore, C.; Crowe, A.; Smith, A.B.; Lee, V.M.Y.; Trojanowski, J.Q. Taudirected drug discovery for Akyheimer's disease and related tauopathies: A focus on tau assembly inhibitors. Exp. Neurol. 2010, 223, 304-310.

97. Taniguchi, S.; Suzuki, N.; Masuda, M.; Hisanaga, S.; Iwatsubo, T.; Goedert, M.; Hasegawa, M. Inhibition of heparin-induced tau filament formation by phenothiazines, polyphenols and porphyrins. J. Biol. Chem. 2005, 280, 7614-7623.

98. Congdon, E.E.; Figueroa, Y.; Wang, L.; Toneva, G.; Chang, E.; Kuret, J.; Conrad, C.; Duff, K. Inhibition of tau polymerization with cyanide dye in two distinct model systems. J. Biol. Chem. 2009, 284, 20830-20839.

99. Bulic, B.; Pickhardt, M.; Khlistunova, I.; Biernat, J.; Mandelkow, E.M.; Mandelkow, E.; Waldmann H. Rhodamine-based tau aggregation inhibitors in cell models of tauopathy. Angew. Chem. Int. Ed. 2007, 46, 1-6. 
100. Korth, C.; May, B.C.H.; Cohen, F.E.; Prusiner, S.B. Acridine and phenothiazine derivatives as pharmacotherapeutics for prion disease. Proc. Natl. Acad. Sci. USA 2001, 98, 9836-9841.

101. Priola, S.A.; Raines, A.; Caughey, B. Porphyrin and phthalocyanide antiscrapie compounds. Science 2000, 287, 1503-1506.

102. May, B.C.H.; Fafarman, A.T.; Hong, S.B.; Rogers, M., Deadly, L.W.; Prusiner, S.B. Cohen, F.E. Potent inhibition of scrapie prion replication in cultured cells by bis-acridine. Proc. Natl. Acad. Sci. USA 2003, 100, 3416-3421.

103. Hays, S.J.; Levine, III H.; Scholten J.D. Inhibition of Amyloidosis by 9-Acridinones, US-5, 1999, $972,956$.

104. Dzierzbicka, K.; Kawzowicz, A.; Koc, A.; Kukowska-Kaszuba, M. Acridine/acridone derivatives —-synthesis, biological activity and clinical application. Wiadomosci Chem. 2009, 63, 107.

105. Shimadzu, H.; Suemoto, T.; Suzuki, M.; Shiomitsu, T.; Okamura, N.; Kudo, Y.; Sawada, T.; A novel probe for imaging amyloid-b: Synthesis of F-18 labelled BF-108, an Acridine Orange analog. J. Labelled Compd. Radiopharm. 2003, 46, 765-772.

106. Suemoto, T.; Okamura, N.; Shiomitsu, T.; Suzuki, M.; Shimadzu, H.; Akatsu, H.; Yamamoto, T.; Kudo, Y.; Sawada, T. In vivo labeling of amyloid with BF-108. Neurosci. Res. 2004, 48, 65-74.

107. Gazova, Z.; Bellova, A.; Daxnerova, Z.; Imrich, I.; Kristian, P.; Tomascikova, J.; Bagelova, J.; Fedunova, D.; Antalik, M. Acridine derivatives inhibit lysozyme aggregation. Eur. Biophys. J. 2008, 37, 1261-1270.

108. Antosova, A.; Chelli, B.; Bystrenova, E.; Valle, F.; Imrich, J.; Kristian, P., Biscarini, F.; Gazova, Z. Structure-activity relationship of acridine derivatives to amyloid aggregation of lysozyme. BBA-General Subjects 2011, in press.

109. Bellova, A.; Balogova, L.; Chelli, B.; Bystrenova, E.; Valle, F.; Imrich, J.; Kristian, P.; Drajna, L.; Bagelova, J.; Biscarini, F.; Gazova, Z. Glycosyl acridines reducing lysozyme amyloid aggregation, Eur. Biophys. J. 2009, 38, 129.

110. Dolphin, G.T.; Chierici, S.; Ouberai, M.; Dumy, P.; Garcia, J. A multimeric Quinacrine conjugate as a potential inhibitor of Alzheimer's beta-amyloid fibril formation. ChemBioChem 2008, 9, 952-963.

111. Sperling, L.E.; Steinert, G.; Boutter, J.; Landgraf, D.; Hescheler, J.; Pollet, D.; Layer, P.G. Characterisation of cholinesterase expression during murine embryonic stem cell differentiation. Chem. Biol. Interact. 2008, 175, 156-160.

112. Lev-Lehman, E.; Deutsch, V.; Eldor, A.; Soreq, H. Immature human megakaryocytes produce nuclear-associated acetylcholinesterase. Blood 1997, 89, 3644-3653.

113. Soreq, H.; Katz, A.; Richler, C.; Malinger, G.; Zakut, H. Expression of cholinesterase genes in human germline cells: implications on reproduction. Am. J. Obst. Gynecol. 1990, 1, 111-113.

114. Karpel, R.; Ben Aziz-Aloya, R.; Sternfeld, M.; Ehrlich, G.; Ginzberg, D.; Tarroni, P.; Clementi, F.; Zakut, H.; Soreq, H. Expression of three alternative acetylcholinesterase messenger RNAs in human tumor cell lines of different tissue origins. Exp. Cell. Res. 1994, 210, 268-277.

115. Drews, U. Cholinesterase in embryonic development. Prog. Histochem. Cytochem. 1975, 7, 1-52.

116. Grisaru, D.; Sternfeld, M.; Eldor, A.; Glick, D.; Soreq, H. Structural roles of acetylcholinesterase variants in biology and pathology, Eur. J. Biochem. 1999, 264, 672-686. 
117. Toiber, D.; Soreq, H. Cellular stress reaction as putative cholinergic links in Alzhemer's disease. Neurochem. Res. 2005, 30, 909-919.

118. Inestrosa, N.C.; Alvarez, A.; Perez, C.A.; Moreno, R.D.; Vicente, M.; Linker, C.; Casanueva, O.I.; Soto, C.; Garrido, J. Acetylcholinesterase accelerates assembly of amyloid-beta-peptides into Alzheimer's fibrils: possible role of the peripheral site of enzyme. Neuron 1996, 16, 881-891.

119. Day, T.; Greenfield, S.A. A peptide derived from acetylcholinesterase induces neuronal cell death: characterization of possible mechanisms Exp. Brain Res. 2003, 153, 334-342.

120. Moran, M.A.; Mufson, E.J.; Gomez-Ramos, P. Colocalization of cholinesterases with beta amyloid protein in aged and Alzheimer's brains. Acta Neuropathol. 1993, 85, 362-369.

121. Mesulam, M.; Carson, K.; Price, B.; Geula, C. Cholinesterases in the amyloid angiopathy of Alzheimer's disease. Ann. Neurol. 1992, 31, 565-569.

122. McGleenon, B.M.; Dynan, K.B.; Passmore, A.P. Acetylcholinesterase inhibitors in Alzheimer's disease. Br. J. Clin. Pharmacol. 1999, 48, 471-480.

123. Zhang, J.T. New drugs derived from medicinal plants. Therapie 2005, 57, 137-150.

124. Zhang, H.Y.; Yan, H.; Tang, X.C. Non-cholinergic effects of Huperzine A: beyond inhibition of acetylcholinesterase. Cell. Mol. Neurobiol. 2008, 28, 173-183.

125. Mukherjee, P.K.; Kumar, V.; Mal, M.; Houghton, J. Acetylcholine inhibitors from plants. Phycomedicine 2007, 14, 289-300.

126. Akaike, A.; Takada-Takatori, Y.; Kume, T.; Izumi, Y. Mechanisms of neuroprotective effects of nicotine and acetylcholinesterase inhibitors: role of alpha4 and alpha7 receptors in neuroprotection. J. Mol. Neurosci. 2010, 40, 211-216.

127. Rodríguez-Franco, M.I.; Fernández-Bachiller, M.I.; Pérez, C.; Hernández-Ledesma, B.; Bartolomé, B. Novel tacrine-melatonin hybrids as dual-acting drugs for Alzheimer disease, with improved acetylcholinesterase inhibitory and antioxidant properties. J. Med. Chem. 2006, 49, 459-462.

128. Fernández-Bachiller, M.I.; Pérez, C.; Campillo, N.E.; Páez, J.A.; González-Muñoz, G.C.; Usán, P.; García-Palomero, E.; López, M.G.; Villarroya, M.; García, A.G.; Martínez, A.; RodríguezFranco, M.I. Tacrine-melatonin hybrids as multifunctional agents for Alzheimer's disease, with cholinergic, antioxidant, and neuroprotective properties. ChemMedChem 2009, 4, 828-841.

129. Silverman, R,B. Design of selective neuronal nitric oxide synthase inhibitors for the prevention and treatment of neurodegenerative diseases. Acc. Chem. Res. 2009, 42, 439-451.

130. Wang, H.; Carlier, P.; Ho, W.L.; Wu, D. Ch.; Lee, Nelson, T.K.; Li, C.P.L.; Pang, Y.P.; Han, Y. Effects of bis(7)-tacrine, a novel anti-Alzheimer's agent, on rat brain AChE. Neuropharmacology 1999, 10, 789-793.

131. Li, W.; Xue, J.; Niu, C.; Fu, H.; Lam, C.S.; Luo, J.; Chan, H.H.; Xue, H.; Kan, K.K.; Lee, N.T.; Li, C.; Pang, Y.; Li, M.; Tsim, K.W.; Jiang, H.; Chen, K.; Li, X.; Han, Y. Synergistic neuroprotection by bis(7)-tacrine via concurrent blockade of $N$-methyl-D-aspartate receptors and neuronal nitric-oxide synthase. Mol. Pharmacol. 2007, 71, 1258-1267.

132. Lupp, A.; Appenroth, D.; Fang, L.; Decker, M.; Lehmann, J.; Fleck, C. Tacrine-NO donor and tacrine-ferulic acid hybrid molecules as new anti-Alzheimer agents: hepatotoxicity and influence on the cytochrome P450 system in comparison to tacrine. Arzneimittelforschung 2010, 60, 229-237. 
133. Chen, X.; Yan, S.D. Mitochondrial Abeta: a potential cause of metabolic dysfunction in Alzheimer's disease. IUBMB Life 2006, 58, 686-694.

134. Hansson, P.C.A.; Alikhani, N.; Behbahani, H.; Wiehager, B.; Pavlov, P.F.; Alafuzoff, I.; Leinonen, V.; Ito, A.; Winblad, B.; Glaser, E.; Ankarcrona, M. The amyloid beta-peptide is imported into mitochondria via the TOM import machinery and localized to mitochondrial cristae. Proc. Natl. Acad. Sci. USA 2008, 105, 13145-13150.

135. Muirhead, K.E.; Borger, E.; Aitken, L.; Conway, S.J.; Gunn-Moore, F.J. The consequences of mitochondrial amyloid beta-peptide in Alzheimer's disease. Biochem. J. 2010, 426, 255-270.

136. Cardoso, S.M.; Pereira, C.F.; Moreira, P.I.; Arduino, D.M.; Esteves, A.R; Oliveira, C.R. Mitochondrial control of autophagic lysosomal pathway in Alzheimer's disease. Exp. Neurol. 2010, 223, 194-198.

137. Eskelinen. E.L.; Saftig, P. Autophagy: a lysosomal degradation pathway with a central role in health and disease. Biochim. Biophys. Acta 2009, 1793, 664-673.

138. Rami, A. Review: autophagy in neurodegeneration: firefighter and/or incendiarist? Neuropathol. Appl. Neurobiol. 2009, 35, 449-61.

139. Santos, R.X.; Cardoso, S.; Correia, S.; Carvalho, C.; Santos, M.S.; Moreira, P.I. Targeting autophagy in the brain: a promising approach? Cent. Nerv. Syst. Agents Med. Chem. 2010, 10, 158-168.

140. Cherra, S.J.; Chu, C.T. Autophagy in neuroprotection and neurodegeneration: A question of balance. Future Neurol. 2008, 3, 309-323.

141. Martinet, W.; Agostinis, P.; Vanhoecke, B.; Dewaele, M.; De Meyer, G.R. Autophagy in disease: a double-edged sword with therapeutic potential. Clin. Sci. (Lond) 2009, 116, 697-712.

142. Funderburk, S.F.; Marcellino, B.K.; Yue, Z. Cell "self-eating" (autophagy) mechanism in Alzheimer's disease. Mt. Sinai J. Med. 2010, 77, 59-68.

143. Rajawat, Y.S.; Bossis, I. Autophagy in aging and in neurodegenerative disorders. Hormones (Athens) 2008, 7, 46-61.

144. Escobar-Khondiker, M.; Höllerhage, M.; Muriel, M.P.; Champy, P.; Bach, A.; Depienne, C.; Respondek, G.; Yamada, E.S.; Lannuzel, A.; Yagi, T.; Hirsch, E.C.; Oertel, W.H.; Jacob, R.; Michel, P.P.; Ruberg, M.; Höglinger, G.U. Annonacin, a natural mitochondrial complex I inhibitor, causes tau pathology in cultured neurons. J. Neurosci. 2007, 27, 7827-7837.

145. Mattson, M.P.; Chan, S.L. Calcium orchestrates apoptosis. Nat. Cell Biol. 2003, 5, 1041-1043.

146. Rizzuto, R.; Pinton, P.; Ferrari, D.; Chami, M.; Szabadkai, G.; Magalhães, P.J.; Di Virgilio, F.; Pozzan, T. Calcium and apoptosis: facts and hypotheses. Oncogene 2003, 22, 8619-8627.

147. LaFerla, F.M. Calcium dyshomeostasis and intracellular signaling in Alzheimerś disease. Nat. Rev. Neurosci. 2002, 3, 862-872.

148. Stieren, E.; Werchan, W.P.; El Ayadi, A.; Li F.; Boehning, D. FAD mutations in amyloid precursor protein do not directly perturb intracellular calcium homeostasis. PLoS One 2010, 5, e11992.

149. Supnet, C.; Bezprozvanny, I. Neuronal calcium signaling, mitochondrial dysfunction, and Alzheimer's disease. J. Alzheimers Dis. 2010, 20, 487-498. 
150. Zhu, H.; Gao, W.; Jiang, H.; Jin, Q.H.; Shi, Y.F.; Tsim, K.W.K.; Zhang, X.J. Regulation of acetyltransferase expression by calcium signaling calcium ionophore A23187-and thapsigargininduced apoptosis. Int. J. Biochem. Cell Biol. 2007, 39, 93-108.

151. Green, K.N; LaFerla, F.M. Linking calcium to Abeta and Alzheimer's disease. Neuron 2008, 59, 190-194.

152. Kelly K.M.; Gross R.A.; McDonald R.L. Tetrahydroaminoacridine (THA) reduces voltagedependent calcium currents in rat sensory neurons Neurosci. Lett. 1991, 132, 247-250.

153. Nilsson, L.; Adem, A.; Hardy, J.; Winblad, B.; Nordberg, A. Do tetrahydroamino-acridine (THA) and physostigmine restore acetylcholine release in Alzheimer brains via nicotinic receptors? Nordberg Neural. Transm. 1987, 70, 357-368.

154. Perry, E.K.; Smith, C.J.; Court, J.A.; Bonham, J.R.; Rodway, M.; Atack, J.R. Interaction of 9amino-1,2,3,4-tetrahydroaminoacridine (THA) with human cortical nicotinic and muscarinic receptor binding in vitro. Neurosci. Lett. 1988, 91, 211-221.

155. de los Ríos, C.; Marco, J.L.; Carreiras, M.D.; Chinchón, P.M.; García, A.G.; Villarroya, M. Novel tacrine derivatives that block neuronal calcium channels. Bioorg. Med. Chem. 2002, 10, 2077-2088.

156. Marco-Contelles, J.; León, R.; de los Ríos, C.; Samadi, A.; Bartolini, M.; Andrisano, V.; Huertas, O.; Barril, X.; Luque, F.J.; Rodríguez-Franco, M.I.; López, B.; López, M.G.; García, A.G.; Carreiras, Mdo. C.; Villarroya, M. Tacripyrines, the first tacrine-dihydropyridine hybrids, as multitarget-directed ligands for the treatment of Alzheimer's disease. J. Med. Chem. 2009, 52, 2724-2732.

157. Greenamyre, J.T.; Maragos, W.F. Neurotransmitter receptors in Alzheimer disease. Cerebrovasc. Brain Metab. Rev. 1993, 5, 61-94.

158. Giacobini, E. Cholinergic receptors in human brain: effects of aging and Alzheimer disease. J. Neurosci. Res. 1990, 27, 548-560.

159. Takada-Takatori, Y.; Kume, T.; Izumi, Y.; Ohgi, Y.; Niidome, T.; Fujii, T.; Sugimoto, H.; Akaike, A. Roles of nicotinic receptors in acetylcholinesterase inhibitor-induced neuroprotection and nicotinic receptor up-regulation. Biol. Pharm. Bull. 2009, 32, 318-324.

160. Chen, G.; Chen, P.; Tan, H.; Ma, D.; Dou, F.; Feng, J.; Yan, Z. Regulation of the NMDA receptor-mediated synaptic response by acetylcholinesterase inhibitors and its impairment in an animal model of Alzheimer's disease. Neurobiol. Aging 2008, 29, 1795-1804.

161. Liu, Y.W.; Luo, J.L.; Ren, H.; Peoples, R.W.; Ai, Y.X.; Liu, L.J.; Pang, Y.P.; Li, Z.W.; Han, Y.F.; Li, C.Y. Inhibition of NMDA-gated ion channels by bis(7)-tacrine: whole-cell and singlechannel studies. Neuropharmacology 2008, 54, 1086-1094.

162. Fang, J.H.; Wang, X.H.; Xu, Z.R.; Jiang, F.G. Neuroprotective effects of bis(7)-tacrine against glutamate-induced retinal ganglion cells damage. BMC Neurosci. 2010, 11, 1-9.

163. Luo, J.; Li W.; Zhao, Y.; Fu, H.; Ma, D.L.; Tang, J.; Li, C.; Peoples, R.W.; Li, F.; Wang, Q.; Huang, P.; Xia, J.; Pang, Y.; Han, Y. Pathologically activated neuroprotection via uncompetitive blockade of $N$-methyl-D-aspartate receptors with fast off-rate by novel multifunctional dimer bis(propyl)-cognitin. J. Biol. Chem. 2010, 285, 19947-19958. 
164. Zhang, X.J.; Yang, L.; Zhao, Q.; Caen, J.P.; He, H.Y.; Jin, Q.H.; Guo, L.H.; Alemany, M.; Zhang, L.Y.; Shi, Y.F. Induction of acetylcholinesterase expression during apoptosis in various cell types. Cell Death Differ. 2002, 9, 790-800.

165. Deng, R.; Li, W.; Guan, Z.; Zhou, J.M.; Wang, Y.; Mei, Y.P.; Li, M.T.; Feng, G.K.; Huang, W.; Liu, Z.C.; Han, Y.; Zeng, Y.X.; Zhu, X.F. Acetylcholinesterase expression mediated by c-JunNH2-terminal kinase pathway during anticancer drug-induced apoptosis. Oncogene 2006, 25, 7070-7077.

166. Park, S.E.; Kim, N.D.; Yoo, Y.H. Acetylcholinesterase plays a pivotal role in apoptosome formation. Cancer Res. 2004, 64, 2652-2655.

167. Park, S.E.; Jeong, S.H.; Yee, S.B.; Kim, T.H.; Soung, Y.H.; Ha, N.C.; Kim, N.D.; Park, J.Y.; Bae, H.R.; Park, B.S.; Lee, H.J.; Yoo Y.H. Interactions of acetylcholin-esterase with caveolin-1 and subsequently with cytochrome $\mathrm{c}$ are required for apoptosome formation. Carcinogenesis 2008, 29, 729-37.

168. Ye, W.; Gong, X.; Xie, J.; Wu, J.; Zhang, X.; Ouyang, Q.; Zhao, X.; Shi, Y.; Zhang, X. AChE deficiency or inhibition decreases apoptosis and $\mathrm{p} 53$ expression and protects renal function after ischemia/reperfusion. Apoptosis 2010, 15, 474-487.

169. Toiber, D.; Berson, A.; Greenberg, D.; Melamed-Book, N.; Diamant, S.; Soreq, H. $\mathrm{N}$-acetylcholinesterase-induced apoptosis in Alzheimer's disease. PLoS One 2008, 3, e3108.

(C) 2011 by the authors; licensee MDPI, Basel, Switzerland. This article is an open access article distributed under the terms and conditions of the Creative Commons Attribution license (http://creativecommons.org/licenses/by/3.0/). 